\title{
Vida y organización religiosa castellana en tiempos de Felipe II
}

\author{
(Continuación)
}

\begin{tabular}{|c|c|c|c|c|}
\hline Pueblo 288 & Fiesta 289 & Por qué se guarda ${ }^{2}{ }^{2}$ & Desde cuándo 291 & $\begin{array}{l}\text { Prácticas } \\
\text { piadosas } 292\end{array}$ \\
\hline $\begin{array}{l}\text { Albaladejo } \\
\text { n. }{ }^{\circ} 52\end{array}$ & $\begin{array}{l}\text {-S. Sebastián } \\
\text {-Conv. S. Pablo } \\
\text {-Sta. Quiteria }\end{array}$ & $\begin{array}{l}\text { - por. muerte, lang } \\
\text { rabia y otras cosas. }\end{array}$ & $\begin{array}{l}\text {, - muy antiguo } \\
- \text { muy antiguo }\end{array}$ & -abstinencia \\
\hline
\end{tabular}

288. Debajo de cada pueblo indicamos el número de las Relaciones donde está tratado este aspecto que ahora estudiamos.

.289. Como el lector podrá observar, las fiestas son muchas, teniendo en cuenta que son algo «extra», salvo pequeños errores, es decir, añadidas al calendario oficial de la Iglesia y de la Archidiócesis, que ya en esta época era generoso y abundante; además, casi en todas ellas «se huelga ese día», es decir, que es un día de fiesta total. Era una forma reglada oralmente con todo el peso y la fuerza de ley escrita.

La elección del santo se presta a interrogaciones y dudas, ¿por qué éste y no otro? Ante una necesidad, peligro o urgencia grave y colectiva se escribian en papeletas individuales los nombres de aquellos santos y santas que gozasen de mayor devoción y fervor entre los asistentes. Se pedía a Dios por la pronta solución del problema y se mandaba sacar a un niño pequeño -4 a 6 años- una de las papeletas. El santo cuyo nombre figurase escrito era, a partir de ese momento, el intercesor o encargado directo de llevar los trámites - oraciones, sacrificios, prácticas piadosas, peticiones, etc. - para interceder ante Dios en favor de esas gentes. Esta es una de las razones de que ante una misma plaga, enfermedad o peligro, se tenga distinto intercesor en los diferentes pueblos, y aun dentro del mismo. «La fiesta de San Agustín la juro esta villa por el infortunio que esta dicho de la langosta echando suertes entre los doctores de la Iglesia y cupo la suerte a esta Bienaventurado Santo», Relaciones de Socuéllamos, $n .^{\circ} 53$.

También, a veces, se recurría a nombrar directamente al santo o santa que en el pueblo próximo había favorecido positivamente en un problema semejante o al que la Iglesia oficial proponía ante la veneración de los fieles como abogado e intercesor ante esa calamidad, título que casi siempre había adquirịo por consenso de muchos pueblos ante una misma desgracia solucionada favorablemente.

290. Aunque la lista de motivos es amplia, casi puede reducirse al ciclo de la naturaleza en su compleja gama de fenómenos atmosféricos y faunísticos, tanto por abundancia como por escasez de ellos que ponen en peligroo en cualquier caso las cosechas $\mathrm{y}$, por tanto, el núcleo económico y vital de estas pobres gentes que lo esperan todo del cielo --en el sentido físico de la palabra - y del duro trabajo de sus curtidas manos, sin más intermediarios que una fe, muchas veces egoísta e interesada, pero para ellos lenitivo efectivo - isuperstición? - ante estos problemas concretos.

Fuera del ciclo de la naturaleza nos encontramos con la explicación de que se guarda esa determinada fiesta «por devoción» o «por voto», que muchas veces es la forma genérica de insistir en lo mismo. Algunos casos nos han sorprendide por los motivos puramente religiosos y maduros que les han llevado a festejar a ese santo/a:

- a Sta. Ana: por ser madre de la Virgen María.

- a Ntra. Sra. de la Paz: por la paz y la salud del pueblo cristiano.

En bastantes ocasiones el cumplimiento del voto vemos que se guardó y se mantiene su cumplimiento por los efectos 


\begin{tabular}{|c|c|c|c|c|}
\hline Pueblo & Fiesta & Por qué se guarda & Desde cuándo & $\begin{array}{l}\text { Prácticas } \\
\text { piadosas }\end{array}$ \\
\hline $\begin{array}{l}\text { Alcoba } \\
\text { n. }{ }^{\circ} 52\end{array}$ & $\begin{array}{l}\text { - Lunes Let. Menor. } \\
\text {-S. Bernardino } \\
\text {-Cruz de Mayo } \\
\text {-S. Sebastián }\end{array}$ & $\begin{array}{l}\text {-? } \\
\text { - por langosta } \\
-? \\
\text { - por peste }\end{array}$ & $\begin{array}{l}-? \\
-? \\
-? \\
-?\end{array}$ & -abstinencia 293 \\
\hline
\end{tabular}

positivos y los favores alcanzados; estas gentes pudieron comprobarlo y así lo manifiestan. Aunque indiquemos algunos ejemplos -y por ello precisamente- queda el sabor de que en esos casos el cumplimiento estaba en relación directa a obtener el beneficio, es decir, se trataba de un intercambio de favores; únicamente quedaban excluidos de esta catalogación aquellos en que el motivo ha sido «la devoción» u otro netamente de matiz religioso:

- «... fue plaga inormisima que se comia los frutos de la tierra y despues que se voto nunca mas la habido aunque en la comarca habido mucha, y que no habido cosa que haga daño» (Ballesteros de Calatrava, $\mathrm{n} .^{\circ} 52$ ).

- «... habia necesidad grande de agua al tiempo que se voto que fue el dicho viernes e que otro dia sabado se harto la tierra de agua» (Calzada de Calatrava, $\mathrm{n} .^{\circ}$ 52).

- «... se voto por muchas esterilidades que habia, y que por ser en ello consolados la llamaron Nuestra Señora de la Consolación» (Fontanarejo, n. ${ }^{\circ} 52$ ).

- «... por la langosta mucha que habia habra treinta años poco mas o menos y fue Dios servido que luego ceso aquella plaga" (Piedrabuena, n. ${ }^{\circ} 52$ ).

- «... se voto porque en este termino no llovia y despues de hecho el revoto fue Dios servido de llover por lo cual se coxio mucho pan» (Tomelloso, $n .^{\circ} 41$ ).

- «... votose porque habia mucha langosta que se comia los panes e viñas e frutos de la tierra y luego se consumio la langosta que no se supo que se hizo», (Villamanrique, $\mathrm{n} .^{\circ} 52$ ).

291. Siguiendo la datación y origen de bastantes de estas fiestas y los votos, hemos observado la relativa inmediatez y proximidad a la fecha de la redacción de las Relaciones en que están hechos: en torno a la mitad del siglo.

Siempre es la colectividad la que se hace responsable del voto: «por voto del Concejo» (Alcoba, n. ${ }^{\circ} 52$ ); «tienen hechos votos en congregacion y solemnidad» (Almodóvar del Campo, $n{ }^{\circ}$ 52); «por vecinos desta villa con crden de! roncejo» (Árenas de Sán Juan, n. 52); «por voto del pueblo» y «se voto» (passim)

292. Las prácticas piadosas y de ascesis con que acompañan a estos votos son facilmente clasificables y las podemos reducir a esta estructura:

-piadosas: misa, vísperas, procesión, rezos...

-ascéticas: ayuno, abstinencia...

-asistenciales: caridad, limosna...

Se entiende -y en la mayoría de las Relaciones lo dejan muy claro- que esos ayunos y abstinencias son además de los que prescribe la Santa Madre Iglesia para el pueblo cristiano en general. De ahí que al responder a esta pregunta no insistan en esos otros días que constituían norma de obligado cumplimiento en cualquier parte del mundo católico.

La práctica del ayuno y la abstinencia se solía hacer en la vigilia de la festividad, aunque no hay una medida uniforme.

El concepto de «caridad» como práctica piadosa tuvo un origen netamente asistencial a los necesitados; no cabe duda que con el paso del tiempo se prestaba, por su propia índole, a cometer abusos; ya veremos cómo en estos mismos años de las Relaciones se vigilan, corrigen y cortan en algunos casos las desviaciones.

Nos satisface que en pleno siglo XX, aunque ya sólo en plan de reliquia o vestigio arqueológico, pero con cierto matiz y valor religioso difícilmente clasificable y mesurable, lo hayamos encontrado y conocido en alguno de estos pueblos.

Genéricamente la «caridad» era como una limosna en especie - y aquí la gama y cuantía es inmensa- que después de la fiesta religiosa - misa y/o procesión - se daba a los pobres, a los enfermos, a los niños, a los asistentes, etc. Si primitivamente fue de pan y, poco después, de pan y vino, llegó a sofisticarse tanto que en algunos casos terminó siendo una fiesta o comilona, no ya para los necesitados, sino para el pueblo entero.

Si al comerse la «caridad» era casi preceptivo rezar al santo o santa pidiendo su intercesión por el problema que les había congregado, con el tiempo se debió olvidar este requisito que hacía de la «caridad» un signo religioso para convertirlo en ocasión de otros usos y abusos un poco fuera del contexto que celebraban. Siempre que no indiquemos nada al respecto, la «caridad» era de pan o de pan y vino.

293. «... por costumbre deste Arzobispado», n. ${ }^{\circ} 52$. 


\begin{tabular}{|c|c|c|c|c|}
\hline $\begin{array}{c}\text { Pueblo } \\
\vdots\end{array}$ & Fiesta & Por qué se guarda & Desde cuándo & $\begin{array}{l}\text { Prácticas } \\
\text { piadosas }\end{array}$ \\
\hline Alcolea de Calatrava & —Sta. Escolástica & -por langosta & -mucho tiempo & $\begin{array}{l}-1^{\text {a }} \text { Visp., Misa y } \\
\text { car. }{ }^{294}\end{array}$ \\
\hline n. ${ }^{\circ} 52$ & -S. Gabriel & - por faltar agua & -36 ó 37 años & $\begin{array}{l}\text {-Proc., misa, sermón y } \\
\text { caridad. }\end{array}$ \\
\hline $\begin{array}{l}\text { Alcubillas } \\
\text { n. } 52\end{array}$ & $\begin{array}{l}\text { - La Concepción } \\
\text { - Cruz de Mayo } \\
\text {-S. Juan ante P. L. }\end{array}$ & $\begin{array}{l}\text {-por langosta } \\
-? \\
-?\end{array}$ & -tiempo inmemorial & $\begin{array}{l}\text {-procesión } \\
\text {-procesión } \\
\text {-procesión }\end{array}$ \\
\hline $\begin{array}{l}\text { Alhambra } \\
\text { n. }{ }^{\circ} 52\end{array}$ & $\begin{array}{l}\text {-S. Antón } \\
\text {-S. Sebastián } \\
\text {-Sta. Águeda } \\
\text {-Cátedra de S. Pedro } \\
\text {-S. Benito (2 días) }{ }^{296} \\
\text {-Cruz de Mayo } \\
\text {-S. Vivar } \\
\text {-Sta. Catalina }\end{array}$ & $\begin{array}{l}\text {-por devoción } \\
\text {-por voto } 295 \\
\text { - por piedra } \\
\text {-por langosta } \\
\text { - por devoción } \\
\text { - por agua } \\
\text { - por hielo } \\
\text {-por devoción }\end{array}$ & $\begin{array}{l}-? \\
- \text { de } 1545 \\
-? \\
-? \\
-? \\
-? \\
-? \\
-?\end{array}$ & $\begin{array}{l}-? \\
-? \\
-? \\
\text {-ayuno y abstinencia } \\
-? \\
\text { - procesión y abstinencia } \\
\text {-abstin. y caridad }{ }^{297} \\
-?\end{array}$ \\
\hline $\begin{array}{l}\text { Almadén } \\
\text { n. }{ }^{\circ} 52\end{array}$ & -Sta. Ana & $-?$ & $-?$ & $-?$ \\
\hline $\begin{array}{l}\text { Almedina } \\
\text { n. } .^{\circ} 52\end{array}$ & $\begin{array}{l}\text {-S. Nicasio } \\
\text {-S. Sebastián } \\
\text {-Sta. Catalina }\end{array}$ & $\begin{array}{l}\text {-por peste } \\
-? \\
\text { - por langosta }\end{array}$ & $\begin{array}{l}-? \\
- \text { muy antiguo } \\
-?\end{array}$ & $\begin{array}{l}-? \\
-? \\
-?\end{array}$ \\
\hline $\begin{array}{l}\text { Almodóvar del Campo } \\
\text { n. } 52\end{array}$ & $\begin{array}{l}\text {-S. Gregorio Nac. } \\
\text {-Sta. Aria } \\
\text {-S. Roque } \\
\text {-Stos. Fab. y Sebast. }\end{array}$ & $\begin{array}{l}\text {-por langosta } \\
\text {-por madre de M. } \\
\text {-por peste del reino } \\
\text { - por peste general }\end{array}$ & $\begin{array}{l}\text { - de } 1545-46 \\
\text {-años pasados } \\
\text {-antiguo } \\
\text {-? }{ }^{298}\end{array}$ & $\begin{array}{l}\text {-procesión } \\
\text {-procesión } \\
\text {-procesión } \\
\text {-procesión y misa }\end{array}$ \\
\hline $\begin{array}{l}\text { Arenas de S. Juan } \\
\text { n. } 52\end{array}$ & $\begin{array}{l}\text {-S. Bernabé } \\
\text {-S. Jorge } \\
\text { - La Concepción } \\
\text { - Ntra. Sra. de Marzo }\end{array}$ & $\begin{array}{l}\text {-por peste } \\
\text {-? } \\
\text {-por langosta } \\
\text {-? }\end{array}$ & $\begin{array}{l}-? \\
\text { - de } 1553 \text { aproxim. } \\
\text { - de } 1545 \text { aproxim. } \\
-?\end{array}$ & $\begin{array}{l}\text {-abstinencia } \\
\text {-abstinencia } \\
\text {-abstinencia, libre } \\
\text {-procesión y misa }\end{array}$ \\
\hline
\end{tabular}

294. «... se da caridad a todas las personas que se halla la vispera de la dicha fiesta a visperas, y el dia siguiente a misa», n. ${ }^{\circ} 52$.

295. «... a causa de que el año de cuarenta y cinco sucedio un hundimiento en el Heredamiento de Ruidera a causa de que revento una laguna por la grande avenida y muchedumbre de aguas que sobrevino, la cual rompio y arranco los molinos que a la sazon Su Majestad tenia en el dicho Heredamiento y un grandisimo cerro peñasco e hizo un espantable hundimiento que hoy dia esta de presente y se vieron en grande peligro los que a la sazon residian en el dicho Heredamienton, n. ${ }^{\circ} 52$.

296. Corresponden esas dos fiestas a la conmemoración del santo, una, y a la traslación del cuerpo, la otra, 21 de marzo y 2 de julio, respectivamente.

297. "... se solia y acostumbraba matar un toro y darlo en caridad al pueblo", n. ${ }^{\circ} 52$. El hecho de que hable en pasado puede deberse a que los visitadores de la Orden de Santiago estaban cortando muchos de estos usos porque en algunos lugares se había pasado al abuso, cfr. nota 330.

298. «... de antiquisimo tiempo a esta parte», n. ${ }^{\circ} 52$, y poco más abajo nos da la fecha de $1545-46$. Es sintomático ese desajuste interpretativo para poder evaluar y tener en cuenta el sentido de la proximidad o lejanía que guarda esta gente con relación a las fechas. 


\begin{tabular}{|c|c|c|c|c|}
\hline Pueblo & Fiesta & Por qué se guarda & Desde cuándo & $\begin{array}{l}\text { Prácticas } \\
\text { piadosas }\end{array}$ \\
\hline $\begin{array}{l}\text { Argamasilla de Alba } \\
\text { n. }{ }^{\circ} 52\end{array}$ & $\begin{array}{l}\text {-S. Sebastián } \\
\text {-S. Miguel de mayo } \\
\text {-Sta. Ana }\end{array}$ & $\begin{array}{l}\text {-por muerte }{ }^{299} 4-? \\
\text {-por langosta } \\
\text { - por muerte } \\
301\end{array}$ & $\begin{array}{l}-? \\
-?\end{array}$ & $\begin{array}{l}\text {-ayuno, procesión, misa } \\
\text { misa y carid. }{ }^{300}\end{array}$ \\
\hline $\begin{array}{l}\text { Argamasilla de Calatrava } \\
\text { n. }{ }^{\circ} 52\end{array}$ & $\begin{array}{l}\text {-Stos. Carito y Julita } \\
\text {-S. Miguel de mayo } \\
\text { - La Visitación } \\
\text {-Cruz de maýo }\end{array}$ & $\begin{array}{l}-? \\
-? \\
-? \\
-?\end{array}$ & $\begin{array}{l}-? \\
-? \\
-? \\
-?\end{array}$ & $\begin{array}{l}-? \\
-? \\
-? \\
-?\end{array}$ \\
\hline $\begin{array}{l}\text { Arroba de los Montes } \\
\text { n. }{ }^{\circ} 52\end{array}$ & $\begin{array}{l}\text {-S. Sebastián } \\
\text {-Ntra. Sra. de la Paz }\end{array}$ & $\begin{array}{l}\text {-por peste } \\
\text {-por la paz } \\
{ }^{302}\end{array}$ & $\begin{array}{l}-? \\
-?\end{array}$ & $\begin{array}{l}-? \\
-?\end{array}$ \\
\hline $\begin{array}{l}\text { Ballesteros de Calatrava } \\
\text { n. }{ }^{\circ} 52\end{array}$ & $\begin{array}{l}\text {-La Visitación } \\
\text {-S. Atanasio } \\
\text {-S. Lucas }\end{array}$ & $\begin{array}{l}\text {-por langosta } \\
\text {-por gusano viñas } \\
\text {-por peste }\end{array}$ & $\begin{array}{l}\text {-de } 1547 \\
\text {-antiguo } \\
\text {-de } 1508\end{array}$ & $\begin{array}{l}\text {-abstinencia y proces. } \\
-? \\
-?\end{array}$ \\
\hline $\begin{array}{l}\text { Bolanos de Calatrava } \\
\text { n. }{ }^{\circ} 52\end{array}$ & $\begin{array}{l}\text {-Stos. Cosme y Dam. } \\
\text {-S. Gregorio } \\
\text {-S. Gregorio Nac. } \\
\text {-S. José }\end{array}$ & $\begin{array}{l}\text {-por peste } \\
\text {-? } \\
\text {-por langosta } \\
\text {-por devoción } 304\end{array}$ & $\begin{array}{l}-? \\
-? \\
-? \\
-?\end{array}$ & $\begin{array}{l}-? \\
-? \\
-? \\
-?\end{array}$ \\
\hline $\begin{array}{l}\text { Cabezarados } \\
\text { n. } 52\end{array}$ & $\begin{array}{l}\text {-Sta. Quiteria } \\
\text {-Stos. Roque y Sebast. } \\
\text {-S. Gregorio Nac. } \\
\text { - Cruz de mayo }\end{array}$ & $\begin{array}{l}\text {-por rabia } 305 \\
\text {-por una peste } \\
\text {-por langosta } \\
\text {-por agua y piedra }\end{array}$ & $\begin{array}{l}\text {-muy antiguo } \\
\text {-de } 1545 \text { aprox. } \\
\text {-de } 1545 \text { aprox. } \\
\text {-de } 1571 \text { aprox. }\end{array}$ & $\begin{array}{l}\text {-proces. y caridad } 306 \\
-? \\
-? \\
-?\end{array}$ \\
\hline
\end{tabular}

299. «... porque estando poblado esta villa de Santa Maria de Alba en el Cerrobroñigal, donde esta la ermita de Santo Sebastian se murieron muchos y se depoblo por mortandad», n. ${ }^{\circ} 52$.

300. «... y son obligados $a$ ir en la dicha procesion una persona de cada casa de las mayores (...) y se da caridad de pan, queso y vino", $\mathrm{n} .^{\circ} 52$.

301. «... en esta villa se solia trabajar en el dicho dia y desta causa se voto de guardar», $n .^{\circ} 52$.

302. «... por la paz del pueblo», $n .^{\circ} 52$.

303. «... y otros oficios solemnes», $n .^{\circ} 52$.

304. «... a instancia de Resgente Virues que fue un docto y santo freyle de la Orden de Sancto Domingo de Almagro el cual con su doctrina y sermones pudo tanto que movio a estos pueblos circunvecinos a la votar y murio este año de $1577 »$. n. $^{\circ} 52$.

305. «... e habiendo alguna remision en el guardar el dicho voto acontecio habra cuarenta años poco mas o menos que estando un dia de fiesta en la dehesa boyal desta villa Isabel Martin vecina desta villa y un hermano suyo y otras gentes salio un lobo rabioso de repente e mordio al dicho mozo e le hizo muchas heridas e rabio e murio de ellas, a cabo de ocho o nueve dias de como fue mordido e los ultimos dias como estaba tan rabioso le tuvieron atado con cadenas hasta que murio e asimesmo mordio muchos bueyes e vacas en la dicha dehesa e queriendo el dicho lobo morder a una vaca que estaba parida defendiendo su becerro lo mato el dicho a el dicho lobo, lo cual visto los vecinos desta villa de alli adelante han guardado e guardan el dicho voto antiguo con mucha devoción», n. ${ }^{\circ} 52$.

306. «... se da de comer a todos los pobres que se hallan en esta dicha villa y comen todos los del pueblo en casa del Piortre aquel dia pagando a escote», n. ${ }^{\circ} 52$. 


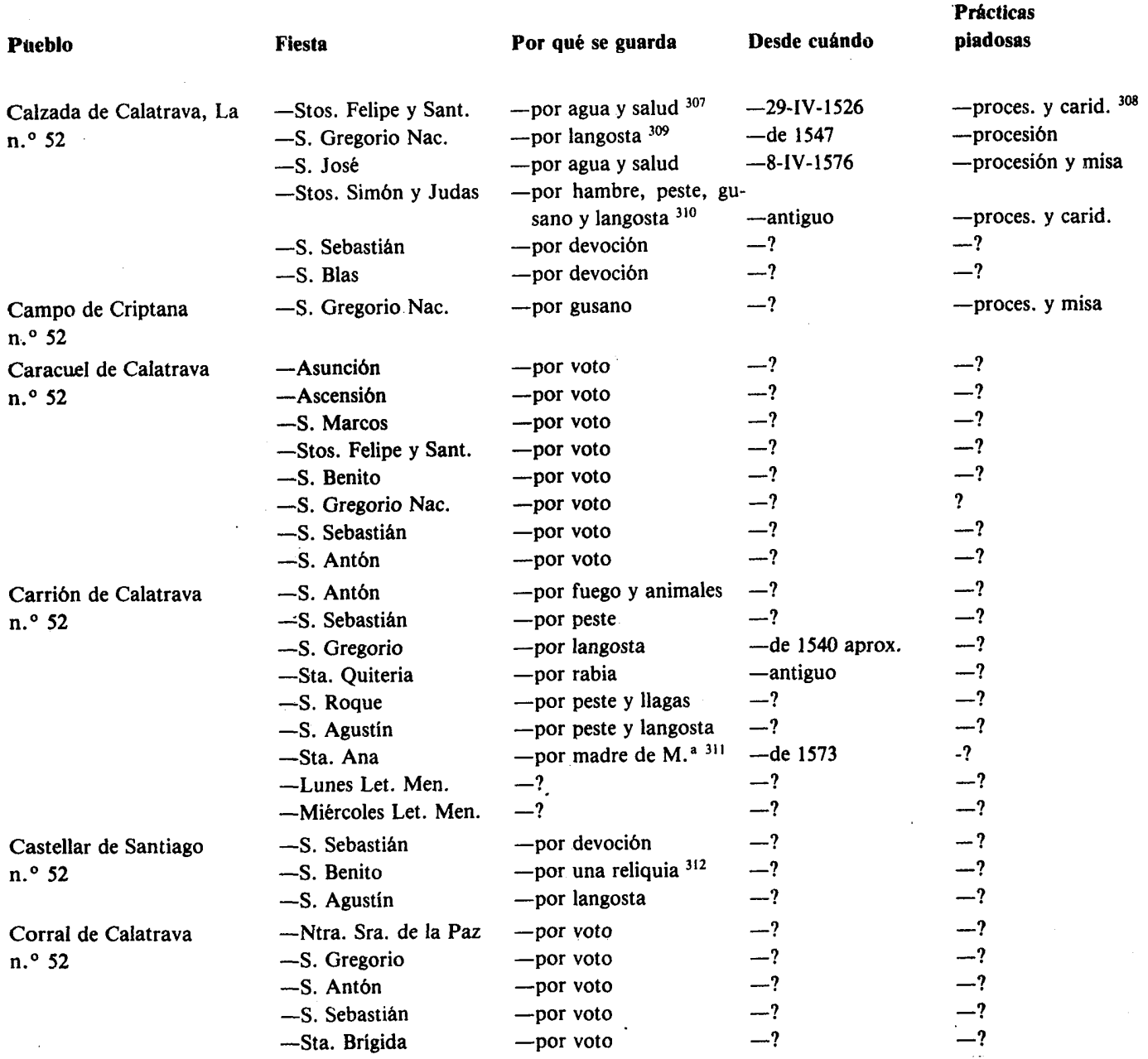

307. «... en el archivo de ella (esta villa) hay una escritura por la cual parece (...) se voto por necesidad de agua y salud (...) e dice en la dicha escritura que habia necesidad grade de agua al tiempo que se voto que fue el dicho dia viernes $e$ que otro dia sabado se harto la tierra de agua», $n .^{\circ} 52$.

308. «... en procesión todo el pueblo», $\mathrm{n} .^{0} 52$.

309. «... y se tomó por abogado señor San Gregorio Nacianceno», n. ${ }^{\circ} 52$. Es una fórmula bastante usada para abreviar el procedimiento que nosotros hemos descrito en la elección de abogado o protector.

310. Esta repetición de diferentes abogados para un mismo problema y en la misma villa puede encontrar justificación y explicación en que ante un mismo problema que el protector anterior no solucionaba había que recurrir a otro nuevo que demostrase benevolencia sin olvidar o incumplir votos y promesas anteriores que bien podrían acarrear conflictos nuevos al verse y sentirse el santo anterior preterido o despreciado.

311. Ya hemos indicado que hay votos cuya cimentación o justificación sí están entroncados con causas de índole religiosa y matices que aun nos sorprenden por su sencillez y delicadeza.

312. «... es por razón que en esta villa esta una reliquia y hueso de señor San Benito», n. ${ }^{\circ} 52$. 


\begin{tabular}{|c|c|c|c|c|}
\hline Pueblo & Fiesta & Por qué se guarda & Desde cuándo & $\begin{array}{l}\text { Prácticas } \\
\text { piadosas }\end{array}$ \\
\hline Cózar & -S. Vicente & -por Tit. parroq. ${ }^{313}$ & $-?$ & $-?$ \\
\hline n. ${ }^{\circ} 52$ & -Sta. Crispina & $-?$ & $-?$ & $-?$ \\
\hline $\begin{array}{l}\text { Chillón } \\
\text { n. }{ }^{\circ} 41\end{array}$ & $\begin{array}{l}\text {-S. Ildefonso } \\
\text {-Sta. Catalina } \\
\text {-Sta. Brígida } \\
\text {-Sta. Lucía }\end{array}$ & $\begin{array}{l}\text {-por devoción } \\
\text {-por devoción } \\
\text {-por devoción } \\
\text { - por devoción }\end{array}$ & $\begin{array}{l}-? \\
-? \\
-?\end{array}$ & $\begin{array}{l}\text {-ayuno, libre } \\
\text {-ayuno, libre } \\
\text {-ayuno, libre } \\
\text {-ayuno, libre }\end{array}$ \\
\hline $\begin{array}{l}\text { Daimiel } \\
\text { n. }{ }^{\circ} 52\end{array}$ & $\begin{array}{l}\text {-S. Roque } \\
\text {-S. Jorge } \\
\text {-S. Gregorio Nac. } \\
\text {-S. Benito } \\
\text { - Ntra. Sra. de la Paz } \\
\text {-Sta. Ana }\end{array}$ & $\begin{array}{l}\text {-por peste } \\
\text {-por hielos } \\
\text {-por langosta } \\
\text {-por } \\
\text { - por terremotos } \\
\text { - por aparición } \\
316 \\
\text {-por devoción }\end{array}$ & $\begin{array}{l}-? \\
-? \\
-? \\
-? \\
-? \\
-?\end{array}$ & $\begin{array}{l}-? \\
-? \\
-? \\
-? \\
-? \\
-?\end{array}$ \\
\hline $\begin{array}{l}\text { Fernancaballero } \\
\text { n. } .^{\circ} 52\end{array}$ & -S. Agustín & - por langosta ${ }^{317}$ & $-?$ & $-?$ \\
\hline $\begin{array}{l}\text { Fontanarejo } \\
\text { n. }{ }^{\circ} 52\end{array}$ & $\begin{array}{l}\text {-N.S. Consolación } \\
\text {-S. Sebastián }\end{array}$ & $\begin{array}{l}\text { - por esterilidades }{ }^{318} \\
\text {-por peste }\end{array}$ & $\begin{array}{l}\text { - de } 50 \text { años } \\
-?\end{array}$ & $\begin{array}{l}-? \\
-?\end{array}$ \\
\hline $\begin{array}{l}\text { Fuencaliente } \\
\text { n. }{ }^{\circ} 51\end{array}$ & $\begin{array}{l}\text {-S. Sebastián } \\
\text {-Convers. S. Pablo }\end{array}$ & $\begin{array}{l}\text {-por peste } \\
\text {-por peste }\end{array}$ & $\begin{array}{l}\text {-mucho tiempo } \\
\text {-mucho tiempo }\end{array}$ & $\begin{array}{l}\text {-ayuno y abstinencia } \\
\text {-ayuno y abstinencia }\end{array}$ \\
\hline $\begin{array}{l}\text { Fuenllana } \\
\text { n. }{ }^{\circ} 52\end{array}$ & $\begin{array}{l}\text {-La Concepción } \\
\text { - Cruz de mayo y sus } \\
\text { vísperas ( } 2 \text { dias) }\end{array}$ & $\begin{array}{l}\text {-por langosta } \\
\text { - por faltar agua }\end{array}$ & $\begin{array}{l}-? \\
-?\end{array}$ & $\begin{array}{l}-? \\
-?\end{array}$ \\
\hline $\begin{array}{l}\text { Herencia } \\
\text { n. }{ }^{\circ} 52\end{array}$ & $\begin{array}{l}\text {-La Concepción } \\
\text {-S. Nicasio } \\
\text {-S. Gregorio } \\
\text {-Vísps. S. Sebast. }\end{array}$ & $\begin{array}{l}\text {-por voto } \\
\text {-por peste } \\
\text {-por langosta } \\
\text {-? }\end{array}$ & $\begin{array}{l}-? \\
-? \\
-?\end{array}$ & $\begin{array}{l}-? \\
-? \\
-? \\
-?\end{array}$ \\
\hline $\begin{array}{l}\text { Horcajo de los Montes } \\
\text { n. } \cdot 50\end{array}$ & -Sto. Toribio & $\begin{array}{l}\text {-por Tit. parroquia y } \\
\text {-advocación lugar } 319\end{array}$ & $-?$ & $-?$ \\
\hline
\end{tabular}

313. «... por ser la parroquial vocacion del dicho santo», $\mathrm{n} .^{\circ} 52$

314. También un mismo destinatario — protección de los frutos_- puede tener más de un abogado, ya que en la mente de estos campesinos no entraba que para asuntos diferentes - hielos o langosta - se pudiera recurrir al mismo protector; cada cosa tenía su intercesor para cada cosa. En definitiva, poco lejos estamos de cualquiera de las mitologías, al menos en cuanto a creencias de premios, castigos, supervivencias, poderes, protectores, etc. «... el dia de San Jorge se voto de guardar por los yelos que hacian mucho daño en los panes y en las viñas desta villa y la fiesta de Sant Gregorio Nacianceno se voto de guardar por la langosta, que hacia gran daño en los frutos de panes y viñas», $n .^{\circ} 52$.

315. «... se voto por grandes terremotos que en aquel dia solian acaecer», $n .^{\circ} 52$. Nos ha sorprendido este motivo, por lo que es en sí, por la forma de su redacción y porque no lo hemos visto indicado en ninguno de los pueblos limítrofes a éste.

316. «... por el milagro con que se fundo", n. ${ }^{\circ} 52$, la aparición de la Virgen que ampliamente queda relatado en el N. ${ }^{\circ}$ 51. Nosotros lo trataremos más adelante al hablar de los milagros. 52.

317. «... porque el Señor nos guardase los panes, y frutos de la langosta que la habia en aquel tiempo mucha», $n .^{\circ}$

318. También se recurre a un voto genérico cuando no están de acuerdo con lo que tienen y esperan mayor seguridad: «... se voto por muchas esterilidades que habia», n. ${ }^{\circ} 52$.

319. Ya hemos visto el problema que existe en este pueblo que figura en dos lugares diferentes con dos titulares de la parroquia distintos, cfr. nota 125 bis; aquí parece que el voto lo guardan «... por ser su advocacion del lugar», n. ${ }^{\circ} 50$. 


\begin{tabular}{|c|c|c|c|c|}
\hline Pueblo & Fiesta & Por qué se guarda & Desde cuándo & $\begin{array}{l}\text { Prácticas } \\
\text { piadosas }\end{array}$ \\
\hline & -S. Sebastián & -por devoción & $-?$ & 二? \\
\hline $\begin{array}{l}\text { Luciana } \\
\text { n. }{ }^{\circ} 52\end{array}$ & $\begin{array}{l}\text {-S. Antón } \\
\text {-S. Sebastián } \\
\text {-Sta. Brígida } \\
\text {-Cátedra S. Pedro } \\
\text {-Sta. M. }{ }^{\text {a Egipciaca }} \\
\text {-S. Gregorio Nac. } \\
\text {-Sta. Ana } \\
\text {-S. Ginés } \\
\text {-Sta. Catalina }\end{array}$ & $\begin{array}{l}\text {-? } \\
\text { - por peste y enferm. } \\
-? \\
\text {-? } \\
\text {-por patrona }{ }^{320} \\
\text { - por pulgón viñas } \\
\text {-? } \\
\text {-por langosta } \\
\text {-? }\end{array}$ & $\begin{array}{l}-? \\
-? \\
-? \\
-? \\
-? \\
-? \\
-? \\
-? \\
-?\end{array}$ & $\begin{array}{l}-? \\
-? \\
-? \\
-? \\
-? \\
-? \\
-? \\
-? \\
-?\end{array}$ \\
\hline $\begin{array}{l}\text { Malagón } \\
\text { n. } 52\end{array}$ & $\begin{array}{l}\text {-S. Pantaleón } \\
\text {-S. Gregorio Nac. } \\
\text {-S. Sebastián }\end{array}$ & $\begin{array}{l}\text {-por langosta y pulgón } \\
\text {-por langosta y pulgón } \\
\text {-por peste }\end{array}$ & $\begin{array}{l}-? \\
-? \\
-?\end{array}$ & $\begin{array}{l}-? \\
-? \\
-?\end{array}$ \\
\hline $\begin{array}{l}\text { Manzanares } \\
\text { n. } 52\end{array}$ & $\begin{array}{l}\text {-Bodas Ntra. Sra. }{ }^{321} \\
\text {-S. Bernabé } \\
\text {-S. León } \\
\text {-S. Mateo } \\
\text {-S. Antón } \\
\text {-S. Sebastián }\end{array}$ & $\begin{array}{l}-? \\
-? \\
-? \\
-? \\
-? \\
-?\end{array}$ & $\begin{array}{l}-? \\
-? \\
-? \\
-? \\
-? \\
-?\end{array}$ & $\begin{array}{l}-? \\
-? \\
-? \\
-? \\
-? \\
-?\end{array}$ \\
\hline $\begin{array}{l}\text { Membrilla } \\
\text { n. }{ }^{\circ} 52\end{array}$ & $\begin{array}{l}\text {-S. León } \\
\text {-S. Agustín }\end{array}$ & $\begin{array}{l}\text {-por hielo } \\
\text {-por langosta }\end{array}$ & $\begin{array}{l}-? \\
-?\end{array}$ & $\begin{array}{l}-? \\
-?\end{array}$ \\
\hline $\begin{array}{l}\text { Miguelturra } \\
\text { n. }{ }^{\circ} 52\end{array}$ & $\begin{array}{l}\text {-S. José } \\
\text {-Sta. Ana } \\
\text {-Sta. Marina } \\
\text {-S. Antón } \\
\text {-S. Sebastián } \\
\text {-La Concepción }\end{array}$ & $\begin{array}{l}\text {-porque asi se han } \\
\text { guardado } \\
322\end{array}$ & $\begin{array}{l}-? \\
-? \\
-? \\
-? \\
-? \\
-?\end{array}$ & $\begin{array}{l}-? \\
-? \\
-? \\
-? \\
-? \\
-?\end{array}$ \\
\hline $\begin{array}{l}\text { Montiel } \\
n .^{\circ} 52\end{array}$ & $\begin{array}{l}\text {-Visp. Corpus } \\
\text {-S. Sebastián } \\
\text {-S. Miguel mayo }\end{array}$ & $\begin{array}{l}\text {-por langosta } \\
\text {-por vocación y peste } \\
\text { - por peste }\end{array}$ & $\begin{array}{l}-? \\
-? \\
-?\end{array}$ & $\begin{array}{l}\text {-ayuno } \\
\text {-abstinencia } \\
-?\end{array}$ \\
\hline $\begin{array}{l}\text { Picón } \\
\text { n. }{ }^{\circ} 1\end{array}$ & -S. Gregorio Nac. & - por langosta & -moderno & $-?$ \\
\hline $\begin{array}{l}\text { Piedrabuena } \\
\text { n. }{ }^{\circ} 52\end{array}$ & $\begin{array}{l}\text {-S. Gregorio Nac. } \\
\text {-S. Sebastián } \\
\text {-Sta. } \mathbf{M}^{\mathbf{a}} \text {. Egipciaca }\end{array}$ & $\begin{array}{l}\text {-por langosta } \\
\text { - por peste } \\
\text {-? }\end{array}$ & $\begin{array}{l}\text {-de } 1545 \text { aprox. } \\
\text {-de } 1555 \text { aprox. } \\
\text {-muy antiguo }\end{array}$ & $\begin{array}{l}-? \\
-? \\
- \text { procesion }\end{array}$ \\
\hline Pozuelos de Calatrava, Los & $\begin{array}{l}\text {-S. Sebastián } \\
\text {-S. Gregorio } \\
\text { - La Visitación }\end{array}$ & $\begin{array}{l}\text { - por devoción } \\
\text { - por langosta } \\
\text {-por devoción }\end{array}$ & $\begin{array}{l}-? \\
-? \\
-?\end{array}$ & $\begin{array}{l}-? \\
-? \\
-?\end{array}$ \\
\hline $\begin{array}{l}\text { Puebla del Príncipe } \\
\text { n. }{ }^{\circ} 34\end{array}$ & -Conv. de S. Pablo & -por peste & $-?$ & $-?$ \\
\hline Puebla de Don Rodrigo & $\begin{array}{l}\text {-Sta. Quiteria } \\
\text {-S. Sebastián }\end{array}$ & $\begin{array}{l}\text {-por rabia } \\
\text {-por peste }\end{array}$ & $\begin{array}{l}-? \\
-?\end{array}$ & $\begin{array}{l}-? \\
-?\end{array}$ \\
\hline
\end{tabular}

320. «... por ser patrona del pueblo y haberse aparecido aqui», $n .^{\circ} 52$.

322. Esta es una razón, contundente por otra parte, que engloba toda una serie de motivos: «... las cuales se guardan por voto y la causa es por que ansi se ha guardado e guarda a el presente en esta villa», $n .^{\circ} 52$. 


\begin{tabular}{|c|c|c|c|c|}
\hline Pueblo & Fiesta & Por qué se guarda & Desde cuándo & $\begin{array}{l}\text { Prácticas } \\
\text { piadosas }\end{array}$ \\
\hline $\begin{array}{l}\text { Puertollano } \\
\text { n. }{ }^{\circ} 52\end{array}$ & $\begin{array}{l}\text {-S. Sebastián } \\
\text {-S. Gregorio Nac. } \\
\text { - Jueves antes Pentec. } \\
\text {-S. Ciles } \\
\text { - La Visitación } \\
\text {-Sta. Ana } \\
\text {-La Concepción }\end{array}$ & $\begin{array}{l}\text {-por devoción y peste } \\
\text { - por langosta } \\
\text { - por peste } \\
\text { - por devoción } \\
\text {-por devoción } \\
\text { - por devoción } \\
\text { - por mucha lluvia }\end{array}$ & $\begin{array}{l}-? \\
- \text { muy antiguo } \\
-? \\
-? \\
-? \\
-? \\
-?\end{array}$ & $\begin{array}{l}\text {-procesion } \\
\text {-procesión } \\
\text {-procesión } \\
\text { - procesión } \\
\text {-procesión } \\
\text {-? } \\
\text { - procesión }\end{array}$ \\
\hline $\begin{array}{l}\text { Retuerta } \\
\text { n. }{ }^{\circ} 52\end{array}$ & $\begin{array}{l}\text {-S. Sebastián } \\
\text {-S. Gregorio Nac. } \\
\text {-S. Pantaleón }\end{array}$ & $\begin{array}{l}\text {-por peste } \\
\text { - por oruga y langosta } \\
\text { - por pulgón viñas }\end{array}$ & $\begin{array}{l}\text { - tiempo pasado } \\
-? \\
-?\end{array}$ & $\begin{array}{l}-? \\
-? \\
-?\end{array}$ \\
\hline $\begin{array}{l}\text { Rostro, El } \\
\text { n. }{ }^{\circ} 52\end{array}$ & $\begin{array}{l}\text {-S. Sebastián } \\
\text {-S. Bernardino } \\
\text {-Sta. Quiteria } \\
\text { - Cruz de mayo }\end{array}$ & $\begin{array}{l}\text { - por peste } \\
\text { - por langosta } \\
\text { - por rabia } \\
\text { - por advocación de } \\
\quad \text { Alcoba }{ }^{324}\end{array}$ & $\begin{array}{l}-? \\
-? \\
-? \\
-?\end{array}$ & $\begin{array}{l}-? \\
-? \\
-? \\
-?\end{array}$ \\
\hline $\begin{array}{l}\text { Saceruela } \\
\text { n. }{ }^{\circ} 52\end{array}$ & $\begin{array}{l}\text {-S. Sebastián } \\
\text {-S. Gregorio } \\
\text {-Sta. Ana } \\
\text { - La Concepción } \\
\text { - Ángel de la Guarda } \\
\text {-S. Eugenio (trasl.) }\end{array}$ & $\begin{array}{l}\text {-por peste } \\
\text {-por langosta } \\
\text { - por promesa } \\
\text {-por promesa } \\
-? \\
-?\end{array}$ & $\begin{array}{l}- \text { de } 1507 \\
-? \\
-? \\
-? \\
-? \\
-?\end{array}$ & $\begin{array}{l}-? \\
-? \\
-? \\
-? \\
-? \\
-?\end{array}$ \\
\hline $\begin{array}{l}\text { Sta. Cruz de Mudela } \\
\text { n. }{ }^{\circ} 52\end{array}$ & $\begin{array}{l}\text {-Cruz de mayo } \\
\text {-S. Bartolomé } \\
\text {-S. Sebastián } \\
\text {-S. Nicasio } \\
\text {-S. Marcos }\end{array}$ & $\begin{array}{l}\text {-por tempororales } \\
\text {-por peste } \\
\text { - por peste } \\
\text { - por peste } \\
\text { - por langosta }\end{array}$ & $\begin{array}{l}-? \\
-? \\
-? \\
-? \\
-?\end{array}$ & $\begin{array}{l}\text { - caridad } 325 \\
\text { - caridad } 325 \\
-? \\
-? \\
\text { - abstinencia }\end{array}$ \\
\hline $\begin{array}{l}\text { Socuéllamos } \\
\text { n. } 52 \text { y } 53\end{array}$ & $\begin{array}{l}\text {-Ntra. Sra. de Nieves } \\
\text {-S. Sebastián } \\
\text {-S. Agustín }\end{array}$ & $\begin{array}{l}\text {-por peste } \\
\text {-por peste } \\
\text {-por langosta }\end{array}$ & $\begin{array}{l}\text {-antiguamente } \\
\text {-antiguamente } \\
-?\end{array}$ & $\begin{array}{l}\text {-ayuno y abst., libre } \\
\text {-ayuno y abst., libre } \\
\text {-ayuno y abst., libre }\end{array}$ \\
\hline $\begin{array}{l}\text { Solana, La } \\
\text { n. } 52\end{array}$ & $\begin{array}{l}\text {-S. Juan Evang. } \\
\text {-S. Agustín } \\
\text {-Stos. Cosme y Dam. } \\
\text {-Último día Pasq. Res. } \\
\text {-Cruz de mayo } \\
\text {-Sta. Catalina } \\
\text {-S. Sebastián } \\
\text {-S. Antón }\end{array}$ & $\begin{array}{l}\text { - por hielos verano } 326 \\
\text { - por langosta } \\
\text { - por gusano y cuqui. } \\
\text {-? } \\
\text { - por peste } \\
\text { - por Tit. parroquia } \\
\text {-? } \\
\text {-? }\end{array}$ & $\begin{array}{l}\text {-antiguamente } \\
-? \\
-? \\
-? \\
-? \\
-? \\
-? \\
-?\end{array}$ & $\begin{array}{l}-1 .^{\mathrm{a}}, 2 .^{\mathrm{a}} \text { Vísp. y misa } \\
\text {-caridad } \\
\text {-? } \\
\text { - procesión y caridad } \\
\text { - procesión } \\
-? \\
-? \\
-?\end{array}$ \\
\hline
\end{tabular}

323. Como en Manzanares, aquí también celebran las Bodas de La Virgen, aunque en otro día y aplicándolo al casc concreto de la peste, cfr. $n .^{\circ} 52$.

324. Aquí tenemos otro dato como es que la dependencia de un pueblo mayor puede ocasionar cierta influencia marcar sus pautas de comportamiento colectivo, cfr. $\mathrm{n} .{ }^{\circ} 52$.

325. «... caridad a todo el pueblo y especialmente a los pobres», n. ${ }^{\circ} 52$.

326. Los redactores de este cuestionario se dejaron influir un poco pomposamente y pasan a identificar temperatu. ras inapropiadas con hielos, o hablan de hielos tardíos de primavera - no extraños en estas tierras - aunque lo llevan has ta fechas demasiado avanzadas. Ya hemos visto en Almodóvar del Campo, cfr. nota 298, algo parecido hablando de las fechas de los votos. 


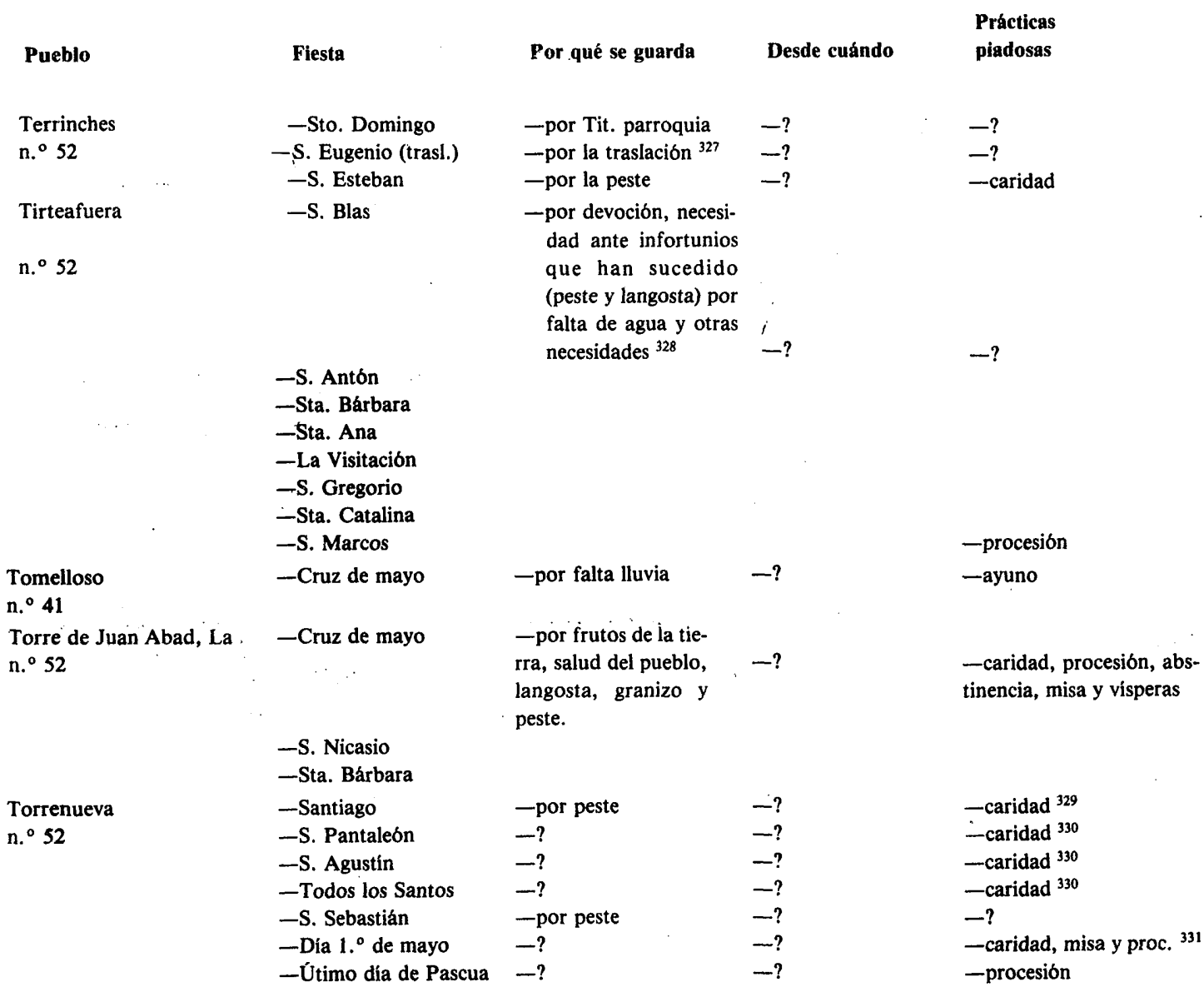

327. Aquí tenemos otro ejemplo de cómo las fiestas o devociones del arzobispado influyen en los pueblos a él sometidos: «... por ser traido el cuerpo deste Arzobispado, huelgase la Traslacion y no el dia», n. ${ }^{\circ} 52$.

328. Aquí no saben qué protector corresponde a qué cosa protegida y engloban todos los santos y todas aquellas cosas en las que necesitan una especial atención, cfr. n. ${ }^{\circ} 52$.

329. «... paga cada vecino de trigo, cebada e centeno que coge de cada doce fanegas del dicho pan un celemin, soliase dar del pan que se llegaba a cada vecino una racion de carne de vaca e pan cocido (...) los vecinos que no siembran no llegando a cahiz pagan un real e medio real los menores y viudas aunque siembren no llegando a doce fanegas la cosecha", n. ${ }^{\circ}$ 52. Esto es lo que se hacía, pero como ya ha llegado la supresión por orden de los Visitadores, dicen: «... y el dia de Santiago una caridad de pan e carne a los niños de todo el pueblo», n. ${ }^{\circ} 52$.

330. «... se solían dar garbanzos e vino y la vispera y dia de cada fiesta de las susodichas y en la visita que hicieron en el año de quinientos e sesenta y cuatro los Visitadores de la Orden de Santiago quitaron las caridades y mandaron que no se de mas que una caridad a los niños el dia de Santiagon, $n .^{\circ} 52$.

331. También aquí curándose en salud deja bien claro lo de la caridad: «... se da caridad de pan que son a los niกิos», n. ${ }^{\circ} 52$. 


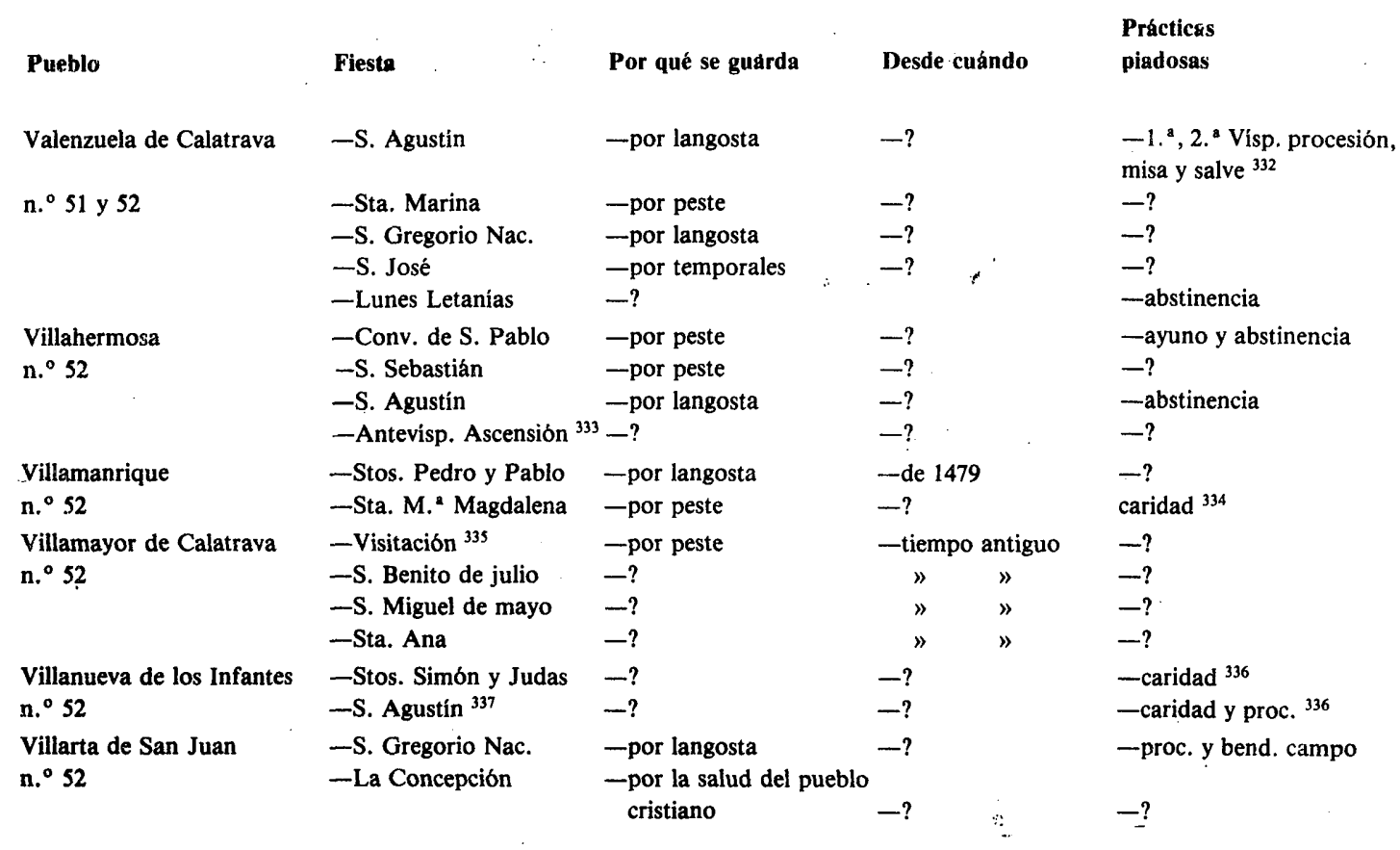

332. Entre las prácticas piadosas, también está la celebración de la Eucaristía por los difuntos del pueblo en general, por los miembros de la Cofradía o Hermandad, etc.: «... misa de requiem por los difuntos, por los cuales oficios arden cantidad de cirios de cera que muchas personas llevan por devoción», n. ${ }^{\circ} 51$.

333. Corresponde al martes de las Letanías.

334. «... se matan dos vacas y se dan en caridad a los vecinos (...) y lo pagan los vecinos», $n .^{\circ} 52$.

335. «... se guardan y celebran con solenidad las fiestas según el calendario de la santa Iglesia romana y arzobispado de Toledo y por voto que el pueblo tiene hecho desde antiguo tiempo a esta parte», $n .^{\circ} 52$. Nuevamente vemos cómo las fiestas particulares del arzobispado marcan a los pueblos de su pertenencia y también cómo un hecho acaecido hace muchos años es suficiente para justificar un voto y una fiesta: «... el dia de la Visitación de Ntra. Sra. del mes de julio el cual dicen los antiguos haberlo votado por gran pestilencia que en este pueblo hubo», $\mathrm{n} .^{\circ} 52$.

336. Aquí también se nota que han pasado los Visitadores de la Orden de Santiago reprimiendo abusos: «... se solía dar caridad de pan y queso y ahora se da en limosna a los pobres», n. ${ }^{\circ} 52$.

337. Como rara excepción tenemos un voto que no se cumple en el día del santo correspondiente: «... se cumple el primer jueves de mayon, n. ${ }^{\circ} 52$. 


\begin{tabular}{|c|c|c|c|c|}
\hline Pueblo & Fiesta & Por qué se guarda & Desde cuándo & $\begin{array}{l}\text { Prácticas } \\
\text { piadosas }\end{array}$ \\
\hline \multirow{17}{*}{$\begin{array}{l}\text { Villarrubia de los Ojos } \\
\text { n. }{ }^{\circ} 52\end{array}$} & -Ntra. Sra. de la Paz & $-?$ & $-?$ & $-?$ \\
\hline & -S. Esteban & $-?$ & $-?$ & $-?$ \\
\hline & -S. Juan Evang. & $-?$ & $-?$ & $-?$ \\
\hline & -Stos. Inocentes & $-?$ & $-?$ & $-?$ \\
\hline & -S. Antón & $-?$ & $-?$ & $-?$ \\
\hline & -Stos. Fabián y Sebast. & $-?$ & $-?$ & $-?$ \\
\hline & -S. Ildefonso & $-?$ & $-?$ & $-?$ \\
\hline & -La Purificación & $-?$ & $-?$ & $-?$ \\
\hline & -S. Matías & $-?$ & $-?$ & $-?$ \\
\hline & -La Anunciación & $-?$ & $-?$ & $-?$ \\
\hline & -S. Marcos & $-?$ & $-?$ & $-?$ \\
\hline & -Stos. Felipe y Sant. & $-?$ & $-?$ & $-?$ \\
\hline & -Cruz de mayo & $-?$ & $-?$ & $-?$ \\
\hline & -S. Gregorio Nac. & $-?$ & $-?$ & $-?$ \\
\hline & -S. Bernabt & $-?$ & $-?$ & -abstinencia \\
\hline & -S. Juan Bautista & $-?$ & $-?$ & -abstinencia \\
\hline & - Las cuatro Témporas & $-?$ & $-?$ & -ayuno \\
\hline $\begin{array}{l}\text { Viso del Marques } \\
\text { n. }{ }^{\circ} 52\end{array}$ & $\begin{array}{l}\text {-S. Sebastián } \\
\text {-Ntra. Sra. Visitación }\end{array}$ & $\begin{array}{l}\text {-por peste } \\
\text {-por incendio iglesia }{ }^{330}\end{array}$ & $\begin{array}{l}\text {-tiempo pasado } \\
\text {-antiguamente }\end{array}$ & $\begin{array}{l}\text {-ayuno la víspera } \\
\text {-ayuno la víspera y pro- } \\
\text { cesión }\end{array}$ \\
\hline
\end{tabular}

338. Nuevamente nos encontramos que una calamidad concreta sirve para marcar el temor del pueblo y tratar de asegurar cierta tranquilidad por medio del voto: «... el dia de la Visitacion de Ntra. Sra. antiguamente se quemo la iglesia de la dicha villa y asi se tomo por voto del y holgar este dia (...) y el dicho dia de señor santo Sebastian ansimismo se toma por voto de holgar su dia de causa que en esta villa en tiempos pasados hubo pestilencia», $\mathbf{n} .^{\circ} 52$. 
Fiestas religiosas particulares (resumen):

-Sobre 63 pueblos estudiados:

- se celebran 250 días de fiesta y corresponden a 3,9 fiestas / pueblo.

- por titulares, tenemos:

- fiestas del Señor .......... 2

- fiestas de la Virgen ........ 27: $\bullet^{\bullet}$ misterios marianos .... 19 fiestas

- advocaciones marianas ..8 8 "

-fiestas de los Santos ..... 155:• apóstoles ........ 22 "

- evangelistas ........6. 6

- mártires ........... 53 ",

- conf. pontífices $\ldots \ldots \ldots 12$ "

- doctores ........... 29 "

- conf. no pontífices .... 21 "

- monjes ........... 8 "

- desconocidos ......... 2 "

- cotitulares .........2 "

—fiestas de las Santas ....... 37:• vírgenes-mártires $\ldots \ldots \ldots 18$,

- vírgenes $\ldots \ldots \ldots \ldots \ldots 4$,

- viudas $\ldots \ldots \ldots \ldots \ldots \ldots 11$,

- penitentes ........... 3 "

-fiestas de los Ángeles ........ 6

- cotitulares ..........

- fiestas de la Cruz de mayo .... 13

- fiestas Letanías-témporas . .... 6

-Otras ................ 4

Total $\ldots \ldots \ldots \ldots \ldots 250$

Por qué se guardan las fiestas particulares (resumen):

-Sobre 63 pueblos estudiados:

- son motivos unidos a los días de fiestas, por tanto seguimos con los 250 como cifra de referencia:

- responden ............... 169

- no responden ............64

- resp. colectivas .......... 17

Total ............... 250

- Motivos:

-por peste ......... 39 fiestas

- " langosta ........ 35 "

- " devoción ........ 19 "

— " voto o promesa ... 17 "

_ " temporales ....... 9 ",

- " sequía ...........5 5 "
Suma anterior ....... 141 fiestas

-por madre de María .... 2

- " celebrarse en el pueblo que dependen ......2

— "la paz ........... 1 "

_ " haber una reliq. . ... 1 ,

—" terremotos ....... 1 " 
Motivos:

_ " titular o patrón ....4 4 "

_. rabia ...........4 ",

_. gusano o pulgón ... 4 ",

_ " salud .......... 3 ",

_ " muerte .........2",

Suma y sigue ... 141
Suma anterior 148 fiestas

_ " una aparición ..... 1 "

_ " esterilidades .....1"

_" incendio..........1 "

_ " varios motivos ... 18 "

Total ....... 169 fiestas

Prácticas piadosas particulares (resumen):

-Sobre 63 pueblos estudiados:

- son prácticas unidas a los días de fiestas locales, por tanto, seguimos con los 250 días de fiestas arriba evaluados:

$\begin{aligned} \text {-responden } \ldots \ldots \ldots \text { 91: } & \bullet 47 \text { corresponden a prácticas } \\ & \text { particulares por fiesta } \\ & \bullet 44 \begin{array}{l}\text { corresponden a prácticas } \\ \text { colectivas por fiesta }\end{array}\end{aligned}$

-no responden 159

Total 250 días de prácticas piadosas establecidas.

- las respuestas representan el $36,4 \%$.

- las prácticas piadosas se estruc-

turan así:

-procesión ...... 18 fiestas

-caridad .......... 11

-abstinencia ......... 11

-ayuno ............ 9 , ,

-ayuno y abstinencia $\ldots . .7 \quad$,,

-procesión y caridad ..... 5 , ,

-procesión y misa ..... 4 , ,

-procesión y abstinencia . 2 , ,

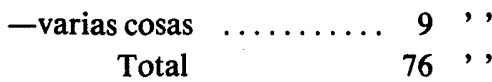

Total

- la diferencia entre las respuestas y las prácticas -91 y 76, respectivamente = a 15- corresponde a aquellos pueblos que unifican en su respuesta una o varias prácticas piadosas con varios días de fiesta. 


\section{Pueblo}

Almodóvar del Campo
Carrión de Calatrava
Chillón

Daimiel

Malagón
Monast. y Orden Relig. ${ }^{339}$

1 Carmelitas descalzos

1 Franciscanos

1 Franciscanos

1 Dominicas

1 Beaterio

1 Beatas Franciscas

1 Carmelitas descalzas
N. ${ }^{\circ}$ relig. Renta

12 ó 13 Sin renta ${ }^{340}$

$6 \quad ?^{341}$

$15 \quad ?^{342}$

$40+2 \quad ?^{343}$

$? \quad ?^{344}$

27

Sin renta ${ }^{345}$

Con renta ${ }^{346}$

339. La vida religiosa institucional no es abundante ni por el número de centros, ni por el número de personas consagradas. Los edificios no son llamativos ni por la arquitectura, ni por las obras de arte atesoradas, ni por cuantiosas o sustantivas rentas. También se observa el fenómeno de la reciente creación en la mayoría de los casos y, en no pocos, no pasan de ser unas modestas casas construidas o donadas por un señor-a y donadas a una determinada orden religiosa.

Más del cincuenta por ciento de los conventos están bajo la Regla franciscana, quedando el resto repartido entre la descalcez carmelitana - de implantación casi simultánea a la redacción de las Relaciones- y la Orden de Sto. Domingo.

340. «... hay de presente doce o trece religiosos y es monasterio nuevamente fundado de un año a esta parte y los frailes son de santa vida y costumbres y que se sustentan de limosnas y residen en una casa pobre y estrecha que el pueblo les dió a cuyo ruego e instancia vinieron a esta villa», . $^{\circ} 53$.

341. «... se dice la Concepcion de Nuestra Señora, tiene al presente seis frailes que vinieron a tomar posesion a veinte dias del mes de julio de mil y quinientos y sesenta y cinco años, es fundador Pedro Naranjo, vecino de esta villa que vive y edifica hoy todavia en el dicho monesterio», $n .^{\circ} 53$. Y refiriéndose al fundador: «... hombre bueno, christiano viejo», $n .^{\circ} 38$.

342. " "... en el cual continuamente hay una quincena de frailes poco mas o menos entre los cuales hay predicadores, confesores y de Misa», $n .^{\circ} 40$. «... de la provincia de los Angeles (...) el cual monesterio dexo y fundo el excmo. Señor D. Diego Fernandez de Cordoba, Marques de Comares, Alcaide de los Donceles de buena memoria habra cien años poco mas o menos tiempo», n. ${ }^{\circ} 42$.

343. «... que dicen de Madre de Dios donde esta un monasterio de monjas de la Orden de Santo Domingo predicador y en el continuamente estan dos frailes del Orden de señor Santo Domingo el uno es Vicario predicador y el otro es un confesor, la cual iglesia y convento dicen haber fundado un hombre que se decia Garcia de Obregon (...) hay cuarenta monjas profesas poco mas o menos», n. ${ }^{\circ} 40$. "La cual fundacion habra cinquenta años poco mas o menos», n. ${ }^{\circ} 42$.

344. «... algunas beatas de santa y religiosa vida que por su devocion las mas de ellas andan vestidas por su casa de blanco», $n .^{\circ} 42$.

345. «... hay al presente veinte y seis beatas con una abadesa, las cuales viven muy recogidas y religiosamente, las cuales son pobres, porque hasta aqui salian a pedir limosna de trigo por los lugares de alrededor (...) y despues questan encerradas padecen mayor necesidad, especialmente de trigo. Han començado a hacer una iglesia de limosnas porque la que tienen es tan pequenica que cabe muy poca gente en ella. El fundador del dicho monesterio fue un caballero de la Orden de Calatrava que fue Comendador desta villa que se llamaba frey Alonso Calvillo, segun fuimos informados que lo fundo y metio una sobrina suya en el monesterio, pero no le dexo renta mas de la casa que hizo comprando para ello ciertas casas de ciertos vecinos e la poca renta que agora tiene en ciertos censos es de los dotes que algunas religiosas han metido", $n .^{\circ} 53$.

346. «... le ha fecho mi señora doña Luisa (de la Cerda), se seis años a esta parte, dotole en cuatrocientos ducados y cien fanegas de trigo perpetuos cada un año y los dotes de las monjas que entran los emplean en renta, habra diez y ocho monjas», $n .^{\circ} 53$. 
Pueblo

Villanueva de los Infantes

Viso del Marqués
Monast. y Orden Relig.

1 Franciscanos
1 Franciscanas
1 Franciscanos
1 Beatas Franciscas

N. ${ }^{\circ}$ Relig. Renta

$\begin{aligned} 40 & ?^{347} \\ 35 & \text { Con renta }{ }^{348} \\ 1 & \text { Sin renta }{ }^{349} \\ 23 & \text { Con } \\ & \text { renta } \\ & \text { 349bis }\end{aligned}$

\section{Vida consagrada (resumen):}

$-\mathrm{N} .{ }^{\circ}$ de monasterios: 11 (de uno no tenemos datos). Distribuidos en 7 pueblos.

$-\mathrm{N} .^{\circ}$ de religiosos: 219 ó 220 .

- Según el número de habitantes de los pueblos estudiados de la Provincia -164.055 - los religiosos suponen el $0,13 \%$ de la población y según el $n .^{\circ}$ de habitantes de los pueblos donde están situados los monasterios $-6.477-$ los religiosos suponen el 3,4\% de la población.

-De varones hay 5 monasterios con un total de 76 ó 77 religiosos.

-De hembras hay 6 monasterios con un total de 143 religiosas.

-A la Orden de San Francisco pertenecen 7 monasterios con 147 religiosos.

-A la Orden del Carmen pertenecen 2 monasterios con 30 ó 31 religiosos.

-A la Orden de Sto. Domingo pertenece 1 monasterio con 42 religiosos.

-Medios económicos: • con renta hay 3 monasterios.

- sin renta hay 3 monasterios.

- no contestan 5 monasterios.

- La renta global de los tres monasterios asciende a 800 ducados y 100 fanegas de tierra.

347. «... fundo un vecino desta villa que se decia Juan Moreno, fue casado y no tuvo hijos, gasto su hacienda en fundar y hacer el dicho monesterio, fue con licencia del Maestre don Alonso de Cardenas, la cual licencia dio el año de mil cuatrocientos y ochenta y tres años, hay en esta cuarenta frailes», $n .^{\circ} 53$.

348. «... es su advocacion la Concepcion de Nuestra Señora, eran beatas que solian salir fuera a misa a San Francisco y a otras cosas a otras partes cuando eran necesarias, hanse encerrado y tienen clausura por el motupropio de Su Santidad y la guaardan bien y han recibido velos y votado clausura el dia de Santo Agustín deste año de setenta y cinco, tienen ducientos ducados de renta poco mas o menos en censos, hay en el dicho monasterio treinta y cinco religiosas. El principio que tuvo fue que habra ochenta años que de su voluntad se recogieron algunas mugeres honradas en una casa para hacer vida monastica y despues dieron la obediencia a la Orden de San Francisco y han vivido siempre en religión y despues una de las dichas mugeres dio una casa y sitio que era suyo a las dichas beatas donde al presente estan no tiene otro titulo mas de posesion y una provision de los Reyes Catholicos por la cual les manda amparar en ella», n. ${ }^{\circ} 53$.

349. «... fundador de el dicho señor Marques y en el de presente no ay mas que un frayle que esta entendiendo en la edificacion del dicho monasterio y no tiene renta ninguna», $n .^{\circ} 53$.

249bis. «Es de beatas de la tercera regla de Señor San Francisco y ay de presente en el beynte y tres beatas y este dizen aberlo fundado un Juan Martín Herrero y catalina Lopez su mujer vecinos que fueron en esta dicha villa y dizen tener de renta y aprovechamiento el dicho monasterio $50.000 \mathrm{mrs}$. poco mas o menos», $\mathrm{n} .^{\circ} 53$. 


\section{Pueblo}

Albaladejo

Alcoba

Alcolea de Calatrava

Alcubillas

Alhambra

Almadén
Hospitales y sus rentas ${ }^{350}$

-1 Sin renta; fundación particular ${ }^{351}$

-1 Sin renta ${ }^{352}$

- 1 Con renta; unido a una cofradía ${ }^{353}$

-1 Sin renta

- 1 Sin renta; fundación particular ${ }^{354}$

- 1 Sin renta; fundación pública ${ }^{355}$

350. El sistema asistencial ha estado en manos de la Iglesia-institución o unido a ella como uno de los fines fundamentales durante siglos. No olvidemos que ella lo asumió conscientemente como tarea fundamental emanáda del mismo evangelio y comportamiento de Cristo en su vida terrena. Incluido como obra de misericordia, se ha preocupado de favorecer la amplia gama que se presenta en este tema - hospitales, asilos, orfanatos, conferencias asistenciales visitas domiciliarias, roperos, cofradías, etc. - y mostrar a la consideración e imitación de los fieles, los bienaventurados que han destacado en estas virtudes.

Que la Iglesia tomase como misión suya el cuidado y asistencia de los pobres, los desvalidos, los enfermos, los menesterosos, etc., era un inmenso beneficio que prestaba a la administración del Estado y a la sociedad en general. Aunque el hecho es de enorme y positiva trascendencia, no excluye que en la práctica estos centros no fuesen todo lo buenos que deberian haber sido; generalmente pequeños y en deficientes condiciones higiénicas, claro, que tampoco la vivienda de los campesinos era buena, acogedora o confortable. Ante la vastedad del problema, la Iglesia exhortó y animó a sus fieles a que le ayudasen en esta caritativa tarea. Sabemos que la respuesta fue generosamente atendida a través de la historia. Ciñéndonos a nuestras coordenadas espaciotemporales, observamos que en la casi totalidad, las erecciones de estos centros se debe a iniciativa privada; en algunos casos están vinculados a una cofradía y en muy pocos ha sido el Concejo el encargado de crearlos.

En dos terceras partes, los fundadores no han podido hacer más que la creación del centro -o donación- siempre humilde y sencillo, $y$, en un tercio, han vinculado una pequeña renta - limosna, dinero, bienes inmuebles - para hacer frente a los gastos más urgentes e imprescindibles. Casi siempre será la caridad de los fieles, transformada en limosnas, lo que saque un poco adelante estos centros.

De las mismas Relaciones entresacamos los fines, destinatarios y requisitos de estos centros, que luego en sus respectivos lugares veremos de un modo taxativo:

- «... para los peregrinos pasageros», (Alcoba, $n .^{\circ} 54$ ).

- «... pobre y mal reparada», (Almodóvar del Campo, $n .^{\circ} 54$ ).

- «... solo se acogen peregrinos», (Bolaños de Calatrava, n. ${ }^{\circ} 54$ ).

- «... se reciben mugeres pobres naturales», (Manzanares, $n .^{\circ} 54$ ).

- «... una mala casilla para hespital», (Puebla del Príncipe, n. ${ }^{\circ} 35$ ).

- «... para pobres que acuden a la dicha villa», (La Solana, n. $\left.{ }^{\circ} 54\right)$.

- «... para personas pobres naturales», (Villanueva de los Infantes, $n .^{\circ} 54$ ).

351. «... hay solamente una casa de hospital y muy pobre, y que no tiene renta ninguna, y que esta casa la dejo para hospital un Sancho Sanchez, difunto, vecino que fue de esta villa», n. ${ }^{\circ}$ 54.

352. «... para los pelegrinos pasageros», $\mathrm{n}^{\circ} 54$

353. «... tiene tres aposentos y lo sustenta la cofradia de San Bartolome», n. ${ }^{\circ} 54$. «... con la renta della (la ermita) reparan (...) un hospital que hay en la dicha villa de camas pobres y lo demas necesario", n. ${ }^{\circ} 51$.

354. «... tiene renta ninguna ni otros bienes mas de las limosnas que se hacen (...) la dicha casa se compro de los bienes de Juan de Vergara difunto (...) habra que se compro y fundo el dicho hospital poco mas de treinta años", $n .^{\circ} 54$.

355. «... es de la villa», n. ${ }^{\circ} 54$. 
Pueblo

Almedina
Almodóvar del Campo

Arenas de San Juan

Argamasilla de Alba

Argamasilla de Calatrava

Arroba de los Montes

Ballesteros de Calatrava

Bolaños de Calatrava

Cabezarados

Calzada de Calatrava, La

Campo de Criptana

Cañada de Calatrava

\section{Hospitales y sus rentas}

-1 Sin renta

- 1 Sin renta; fundación particular. «Sta. María»" ${ }^{356}$

- 1 Con renta; fundación particular, unido a una cofradía. «S. Miguel» ${ }^{357}$

-1 Sin renta ${ }^{358}$

- 1 Sin renta; fundación particular ${ }^{359}$

- 1 Sin renta

- 1 Con renta 360

- 1 Con renta; fundación del Consejo ${ }^{361}$

-1 Sin renta; fundación particular ${ }^{362}$

-1 Sin renta; fundación particular ${ }^{363}$

-1 Sin renta; fundación particular ${ }^{364}$

-1 Con renta. «S. Bartolomé» ${ }^{365}$

-2 ?; fundación particular

-1 Sin renta ${ }^{366}$

356. «... esta a los pies de la iglesia mayor y parroquial y es una casa vieja y pobre y de poco o ningun edificio (...) haber sido fundadores desta casa un fulano Buitrago y su muger, vecinos desta villa», n. ${ }^{\circ} 54$.

357. «... esta en una calle transversal de la que va de la plaza Mayor a la del Altozano y es una casa pobre y mal reparada aunque a ella se acogen la mayor parte de los pobres y peregrinos que pasan y ocurren a esta villa que como es pasagera son muchos continuamente y alli los resciben y curan a los pobres enfermos y en esto se gasta la renta de la Cofradia de señor San Miguel que por ser muy poca y no suficiente se socorre y favorece para la dicha obra pia y limosna depobres de la Cofradia y Hermandad de la limpia Concepcion de Nuestra Señora», n. ${ }^{\circ} 54$.

358. «... se recogen de noche los pobres que por esta villa pasan y que el hespitalero que en el esta para recoger los pobres vive de las limosnas que le dan por el pueblo, porque el hespital es tan pobre que no tiene que dar salario a el hespitalario y los pobres que vienen enfermos los pasa ellos a otra parte, hay necesidad del Concejo para que pague la cabalgadura e se pida de limosna», n. ${ }^{\circ} 54$.

359. «... la dejo la muger de Hernando de Valera, vecina que fue desta villa (...) de limosna se ha ido reedificando y haciendo en ella y que no tiene otra renta mas que las limosnas que se hacen en esta dicha, villa», n. ${ }^{\circ} 54$.

360. «... tiene la renta de treinta colmenas que rentaran treinta reales», n. ${ }^{\circ} 54$.

361. «... el Concejo fue el fundador, tiene de renta un ducado cada año que le dio un particular», n. ${ }^{\circ} 54$.

362. «... dio la casa Teresa Arias de Sandobal, solo se acogen peregrinos», $n .^{\circ} 54$.

363. «... un hospital pobre mando la casa para el un Juan Hidalgo, vecino desta villa no tiene renta mas de lo que se coge de Limosna», n. ${ }^{\circ} 54$.

364. «... donde los pobres forasteros se recogen (...) de las limosnas de esta villa se provee de camas y lo demas, el cual dicho hospital dexo Alonso Martin Ballestero, vecino que fue de esta villa, en el cual dicho hospital hay una capilla dotada» de 300 duc. aprox. para sufragios del Sacristán Mayor de Calatrava, Fray Sebastián de Mera, n. ${ }^{\circ} 54$.

365. «... tiene siete a ocho mil maravedis de renta», $n .^{\circ} 54$.

366. «... lo dejo que se decia Andres Sanchez y fue vecino de la villa de Cozar», n. ${ }^{\circ} 54$. 
Pueblo

Carrión de Calatrava
Castellar de Santiago
Cózar
Chillón

Daimiel

Fernancaballero

Fontanarejo

Fuellana

Herencia

Horcajo de los Montes

Luciàna

\section{Hospitales y sus rentas}

- 1 Sin renta

- 1 Sin renta; fundación particular ${ }^{367}$

- 1 Sin renta; fundación del Concejo ${ }^{368}$

- 1 Sin renta; fundación particular ${ }^{369}$

- 1 Con renta; fundación particular 370

- 1 Con renta; unido a una cofradía. «Ntra. Sra.» ${ }^{371}$

- 1 ?; unido a una cofradía. «Corpus Christi» ${ }^{372}$

- 1 Sin renta; fundación particular, unido a una cofradía. «De la Caridad» ${ }^{373}$

- 1 ?; unido a una cofradía. «Santiago» ${ }^{374}$

-1 Sin renta

-1 Sin renta

- 1 Sin renta ${ }^{375}$

-1 Sin renta. «La Concepción de Ntra. Sra.» ${ }^{376}$

- 1 Sin renta

- 1 Sin renta; fundación del Concejo

367. «... es pobre sin renta ninguna, que se proveen las cosas necesarias de limosnas entre los vecinos», n. ${ }^{\circ} 54$.

368. «... se recogen los pobres forasteros y tiene algunos palacios con su ropa y cama para los dichos pobres y este dicho hospital dicen que lo dexo y formo un Vicario que hubo en esta villa que se decia Juan Bernal y que este hospital terna docientos seis mil maravedis que se gastan en curar los pobres y limpieza y reparo de la casa», n. ${ }^{\circ} 39$.

369. «... dicen que dejo una señora que se decia doña Sabel dentro del cual hay nueve moradas en que moran nueve mugeres pobres y muerta una se recoge otra y que este hospital tie e tres mil maravedis de renta cada un año con que se repara y lo que sobra se da a los pobres del», n. ${ }^{\circ} 39$.

370. «... se reciben los pobres y se curan los enfermos. Tiene cinco o seis mil maravedis de renta y lo que mas se gasta es de limosnas de los cofrades que tiene este hospital», n. ${ }^{\circ} 54$.

371. «... pequeño, que tiene otra cofradia de treinta y tres cofrades que no quieren rescibir mas», $\mathrm{n} .^{\circ} 54$.

372. «... tiene una ermita pequeña en el que se dice misa. Dexole un vecino deste pueblo que se llamo Antonio de Madrid, que habra cuarenta años, y dio otra casa questa encorporada con este hospital para cuatro mujeres pobres, que cada una tiene su aposento, con que sean buenas mujeres. Hay cofradia deste hospital que entierran los difuntos e no tiene otra ninguna renta mas de lo que los cofrades le quieren dar", $\mathrm{n} .^{\circ} 54$.

373. «... esta en la plaza desta villa; hay cofrades y el hospital esta muy pobre. Tiene este pueblo una provision de Su Majestad para reducir todos estos hospitales a uno y no se ha hecho de lo cual hay gran necesidad y los pobres padecen y el pueblo tambien por no se haber hecho", n. 54.

374. «... mas de los bienhechores», n. ${ }^{\circ} 54$.

375. «... no tiene renta, salvo la limosna que se da», $n .^{\circ} 54$.

376. «... acuden los pobres viandantes, el cual no tiene renta ni propio ninguno mas de la limosna que los domingos se pide en la iglesia mientras y al tiempo que se dice la misa mayor entre la buena gente», n. ${ }^{\circ} 54$. 
Pueblo

Malagón

Manzanares

Mernbrilla

Miguelturra

Montiel

Molinillo, El

Piedrabuena

Puebla del Príncipe

Puebla de Don Rodrigo

Puertollano

Saceruela

\section{Hospitales y sus rentas}

-1 Sin renta ${ }^{377}$

- 1 Con renta; fundación particular. «Ntra. Sra.») ${ }^{378}$

-1 Sin renta; fundación particular. «S. Juan» ${ }^{379}$

-1 Sin renta ${ }^{380}$

-1 Con renta ${ }^{381}$

- 1 Sin renta; fundación particular ${ }^{382}$

- 1 Con renta; fundación particular ${ }^{383}$

-1 Con renta. «S. Antón» ${ }^{384}$

- 1 Sin renta.

-1 Sin renta.

- 1 Con renta; fundación particular. «Purificación»" ${ }^{385}$

-1 Sin renta.

-1 Sin renta ${ }^{386}$

-1 Con renta; fundación particular. «Ntra. Sra.» ${ }^{387}$

-1 Con renta; fundación particular. «S. Juan Bpta.» 387

-1 Sin renta ${ }^{388}$

377. "...tiene tres o cuatro camas para los pobres y su mayordomo", n ${ }^{\circ} 54$.

378. «... lo fundo el Comendador Alonso de Avila, habra ochenta años, poco mas o menos y le dexo cierta renta que al presente valdra mil reales, poco mas o menos», n. ${ }^{\circ} 54$.

379. «... lo fundaron los cofrades que hay de esta cofradia y no tiene mas renta de las que le dan», $n .^{\circ} 54$

380. «... se reciben mugeres pobres naturales y no tiene mas renta de lo que le dan del limosnas», n. ${ }^{\circ} 54$.

381. «... cuatro o cinco mil maravedis», $n .^{\circ} 54$.

382. «... dejo Gonzalo de Rios, vecino desta villa para en fin de los dias de su muger quedase para hospital», n. ${ }^{\circ} 54$.

383. «... dejo Hernando Martin Crespo y su muger y hijo para que en el viviesen cuatro personas pobres naturales y se les diese de limosna a cada una seis fanegas de trigo cada un año", n. 04 .

384. «... docientos maravedis poco mas o menos», $\mathrm{n} .^{\circ} 54$.

385. «... a el esta anexada una cofradia de la Purificacion de Nuestra Señora y esta cofradia tiene ciertas tierras de pan llevar (...) y de las rentas destas tierras se repara el dicho hospital y se compran camas y las cosas necesarias para albergar los pobres», $n .^{\circ} 54$.

386. «... de demandas que se hacen y de la demanda de dias de fiesta que se pide es para los pobres que vienen y aun no hay ropa para reparar los pobres», $n .^{\circ} 55$.

387. «... cada uno dellos tiene hasta diez o doce fanegas de tierras y cada dos mil maravedis de renta en cada un año que les dijo Gonzalo Vazquez difunto, vecino que fue desta villa", $n .{ }^{\circ} 54$.

388. «... se recogen todos los pobres viandantes e no tiene ninguna renta sino las limosnas del pueblo e dos camas que se han hecho de poco aca por los sacerdotes y otros religiosos», n. 54. 


\section{Pueblo}

Santa Cruz de Mudela

Socuéllamos

Solana, La

Terrinches

Tirteafuera

Tomelloso

Torre de Juan Abad, La

Torrenueva

Valenzuela de Calatrava

Villahermosa

Villamanrique

Villamayor de Calatrava

\section{Hospitales y sus rentas}

- 1 Sin renta; fundación particular, unido a una cofradía. «Sta. María» ${ }^{389}$

-1 Sin renta; fundación particular ${ }^{390}$

- 1 Con renta; fundación particular ${ }^{391}$

- 1 Con renta; fundación particular ${ }^{392}$

- 1 Sin renta.

- 1 Sin renta; fundación particular ${ }^{393}$

- 1 ?; fundación particular ${ }^{394}$

- 1 Con renta; fundación particular ${ }^{395}$

- 1 Sin renta; fundación del Concejo.

- 1 Sin renta; fundación particular ${ }^{396}$

- 1 Con renta 397

-1 Con renta. «S. Pedro» ${ }^{398}$

- 1 Con renta; fundación desconocida ${ }^{399}$

389. «... esta a cargo de proveer por los cofrades de la cofradia de Nuestra Señora Santa Maria la Mayor y por los dichos cofrades fue ordenado el dicho hospital donde se recogen todo genero de pobres forasteros y el dicho hospital no tiene otra renta mas que las limosnas de las buenas gentes y lo que demas falta para proveer el dicho hospital y sus necesidades se provee del trabajo de los cofrades porque para ello siembran trigo de compañia todos los dichos cofrades de la dicha cofradia», n. ${ }^{\circ} 54$.

390. «... fundole una muger antigua que se llamaba Isabel Rodriguez (...) parece haber dejado solamente las casas con tres camas (...) y otras casas arrimadas a ella para su reparo» (del hospital y una ermita), n. ${ }^{\circ} 54$.

391. «... se reciben los pobres que acuden a la dicha villa cuya casa se dice que fue de un hombre principal de la dicha villa que la dejo para el dicho hospital que se decia Sancho Lopez, tiene ciertas rentas que se arriendan comunmente por diez mil maravedis poco mas a menos cada año", n. ${ }^{\circ} 54$.

392. «... hay cuatro o cinco aposentos en los cuales se recibe para vivir en ellos mugeres pobres y honestas y es posada de frailes esta junto y apegada a la ermita de Nuestra Señora de la Asunción, que lo dexaron y fundaron los dichos Bachiller Savina y sus hermanos juntamente con la fundacion de la dicha ermita», n. ${ }^{\circ} 54$.

393. «.. mas de lo que le dan algunos vecinos por amor de Dios por su devocion y que tiene un mayordomo que tiene cuenta con ello y que la casa del dicho hospital se dice en el dicho lugar que lo dejo un fulano de Cuerva el año de mil quinientos trece», n. ${ }^{\circ} 54$.

394. «... fundo Juan Galindo para recoger los pobres», n. ${ }^{\circ} 39$.

395. «... para recogimiento de los pobres pasageros el cual dejaron Mari Lopez, la Vieja y Bernal Sanchez difuntos, el cual es muy poca renta», $n .^{\circ} 54$.

396. «... de pobres viandantes y no tiene renta, mandolo la platera vieja», n. ${ }^{\circ} 54$.

397. «... dos mil maravedis cada un año», $n .^{\circ} 54$.

398. «... tiene de renta un celemin de cada caiz de trigo que coge cada labrador, que valdra un año con otro sesenta hanegas y gastase en llevar pobres y en otros gastos necesarios a el dicho hospital como es ropa y en una caridad que se da a los pobres", $n .^{\circ} 54$.

399. «... no ay memoria de quien lo fundo por ser de tiempo inmemorial y tiene de renta una carta de censo ques de veynte ducados el principal y asi mismo tiene otros cuarenta ducados en dineros pocos mas o menos los cuales mandaron Gonzalo Fernandez de Cordoba comendador que fue desta villa y otras personas para reparos del dicho hospital y asi se an gastado en los dichos reparos», n. ${ }^{\circ} 54$. 


\section{Pueblo}

Villanueva de los Infantes

Villarta de San Juan

Villarrubia de los Ojos

Viso del Marqués

\section{Hospitales y sus rentas}

- 1 Sin renta; fundación del Concejo 400

- 1 Sin renta; fundación particular. «Santiago»" ${ }^{401}$

-1 Con renta; fundación particular ${ }^{402}$

- 1 Sin renta.

- 1 Con renta ${ }^{403}$

- 1 Sin renta; fundación particular. «Ntra. Sra. de la Consolación»" ${ }^{404}$

-1 Sin renta; fundación particular. «Ntra. Sra. la Mayor» 404 bis

\section{Hospitales (resumen)}

-Sobre 56 pueblos estudiados:

- N. ${ }^{\circ}$ de hospitales: 72.

- O rigen de los hospitales:

$$
\begin{aligned}
& \text { - fundación particular ........33 hospitales } \\
& \text { — fundación del Concejo ....... } 5 \text { hospitales } \\
& \text { - fundación pública } \ldots \ldots \ldots \ldots . \quad 1 \text { hospitales } \\
& \text { — fundación desconocida ....... } 1 \text { hospitales } \\
& \text { - no responden } \ldots \ldots \ldots \ldots \ldots . .32 \text { hospitales } \\
& \text { Total ............. } 72 \text { hospitales }
\end{aligned}
$$

400. «... se curan algunos enfermos de limosnas particulares, que no tiene renta, instituyole el concejo por ser necesario», n. ${ }^{\circ} 54$.

401. «... lo dejo Juan Perez Cañuto», n. ${ }^{\circ} 54$.

402. «... lo dejo doña Luisa (Lucia) de Castellanos, madre de don Fray Thomas de Villanueva, Arzobispo que fue de Valencia, tiene para los reparos la renta de una huerta que renta cuatro ducados», n. ${ }^{\circ} 54$.

403. «... se recogen los pobres que terna hasta catorce reales de renta porque es muy pobre y que no se tien $\epsilon$ noticia de quien mando la dicha casa y renta», $n .^{\circ} 54$.

404. «El uno de ellos se llama de la cofradía de Ntra. Sra. de la Consolación del cual dizen aber sido fundadores los dichos Juan Martin Herrero e la dicha Catalina Lopez en el tiempo que fundaron el dicho monesterio, no sabemos que tenga renta el dicho espital», n. ${ }^{\circ} 54$.

404bis. «Se llama de Stma. Sra. la Mayor el que dizen aber fundado un Miguel Ruiz vecino que fue de esta villa dejando para ello la casa en que el bibía», $n .^{\circ} 54$. 
- Renta de los hospitales:

- de limosnas públicas no especificadas: 3 .

- en dinero (unificando la renta a maravedises, siguiendo la equivalencia de 1 duc. $=375$ mrs. y 1 rs. $=34 \mathrm{mrs} .98 .071$ a $95.071 \mathrm{mrs}$.

- en especie: -76 fan. de fruto (cereales).

- en especie: - 20 ó 24 fan. de tierra.

- en especie: $\bullet 1$ huerta.

- No especifican la renta: 2.

- Unidos a una cofradía: 7.

\begin{tabular}{lll} 
& \multicolumn{2}{l}{ Obras pías, patronatos, fundaciones, etc. } \\
Pueblo & Cuantía & Dedicación \\
Almodóv. del Campo & $-?$ (limosnas) & - Socorro a pobres, viudas, huérfa- \\
& & $\operatorname{nos}^{406}$
\end{tabular}

405. La respuesta que hemos encontrado a esta pregunta en la inmensa mayoria de las Relaciones es el silencio - «no tenemos nada que responder a la dicha pregunta»- posiblemente por ignorancia y no falta de existir respuesta. Nos inclinamos a pensar esto por la razón de que pueblos próximos en la geografía, con idéntico nivel de vida, formación y práctica religiosa, sistema de creencias, nivel económico, etc., es extraño que en unos pocos se den este tipo de obras y en el resto, no. Nuestra constante fidelidad a los manuscritos nos hace recoger y operar con las respuestas constatadas en esas Relaciones concretas.

Por estas pocas contestaciones observamos que se reparten en obras de caridad -casamiento, limosna, ayuda en ciertas necesidades - y en oraciones - sufragios - con la salvedad de ayudar al cura que explique el catecismo a los niños, al que predique en la cuaresma y una beca de estudios. Predomina la cuantía en dinero, aunque tampoco falta el legado en especie. Una vez más constatamos que son fundaciones recientes y predomina en una buena parte de ellas el espíritu de clan, ya que las ayudas y beneficios se han de otorgar a los miembros necesitados de las familias de los respectivos fundadores.

406. «... favorece para la dicha obra pia y limosna de pobres de la Cofradia y Hermandad de la limpia Concepcion de Nuestra Señora que en esta villa y en toda su comarca es la mas insigne la mas religiosa y de mayor misericordia y caridad que se sabe, ni halla y es antigua de mas de cinquenta años y tiene su fundacion en titulo de concesion y privilegio de la Santa Sede Apostolica y de provisiones reales de Su Majestad y para ella se eligen en cada un año cuatro deputados del pueblo un sacerdote y tres seglares, los cuales asi en la iglesia como por la villa piden y recogen hostiatin limosnas de pan y dineros y otras cosas e puesto que su principal intento e institucion de Santa obra y cofradia fue y es para socorrer y sustentar a pobres naturales vergonzantes enfermos $e$ invalidos viudas y miserables personas y a esto se atiende con mayor cuidado tambien se favorece y ayuda a los dichos pobres e enfermos forasteros y se acude a visitar y proveer los dichos hospitales», n. ${ }^{\circ} 54$. 
Obras pías, patronatos, fundaciones, etc.

Pueblo

Argamas. de Alba

Manzanares

\section{Cuantía Dedicación}

$\begin{array}{ll}\text { - ? especie } & \text { - Sufragios }{ }^{407} \\ \text { - ? especie } & \\ 12.000 \mathrm{mrs} . & \text { - Casamiento de huérfanas y herra } \\ & \quad \text { das } 408 \\ -5.000 \text { duc. } & \text { - Oraciones y misas }{ }^{409} \\ -50.000 \mathrm{mrs} . & \text { - Casamiento de huérfanas }{ }^{410} \\ -30.000 \mathrm{mrs} . & \text { - Casamiento de huérfanas }{ }^{411} \\ -500 \text { duc. } & \text { - Sufragios, una beca, casamiento }{ }^{412} \\ -40.000 \mathrm{mrs} . & - \text { Casamiento de huérfanas }{ }^{413} \\ -? & - \text { ? }^{414}\end{array}$

407. «... Juan de Zuñiga y su muger dexaron un patronazgo en Cabezas de Alejo de Zuñiga y Maria de Huerta, sus sobrinos en unas casas principales en esta villa con una huerta de arboledas junto a la dicha casa que pasa el dicho rio Guadiana por medio y seiscientas fanegas de tierras con cierto cargo de misas y oficios y hacer ciertas fiestas de Nuestra Señora y del nombre de Jesus perpetuas», n: ${ }^{\circ} 25$.

408. «... dejó el dicho alcaide otra memoria y hacienda de que es patron los alcaldes ordinarios desta villa y el cura y los mayordomos de las cofradias de la Vera Cruz y Santo Sacramento, que es la renta que vale la venta de las Motillas y trescientas fanegas de pan en cada año y doce mil maravedis y esto se gasta en casar dos huerfanas cada año y de cinco en cinco años de han de casar dos mujeres yerradas de la dicha renta», $\mathrm{n}^{0^{\circ}} 54$.

409. " «... Diego de Oropesa y su mujer tienen fundado un patronazgo en cabeza de Juan de Oropesa su hijo con cargo de decir cada semana una misa y hacer la fiesta de Nuestra Señora de la Concepcion y tomar tres bulas de difuntos cada año en el cual puso unas casas principales que tiene en esta villa en la plaza della con lo que va edificando alrededor y una quinteria y tierras con trescientas fanegas de tierras y siete pedazos de Quiñones para cebada junto a esta villa de ciento y veinte fanegas y en otros pedazos a cumplimiento de seiscientas fanegas y un majuelo de siete mil vides que esto valdra cinco mil ducados», $n .^{\circ} 25$.

410. «... instituyo Gonzalo de la Torre y Beatriz Garcia, su muger, vecinos desta villa veinte y ocho años ha poco mas o menos y dejaron cincuenta mil maravedis de renta en cada un año para casar huerfanas pobres de su linage a quien se dan quince mil maravedis a cada una», $n .^{\circ} 54$.

411. «... instituyo Pedro Gimenes, vecino desta villa, quince años ha, y dejo treinta mil maravedis de renta en cada un año para casar huerfanas de su linage pobres y se les da quince mil maravedis», n. ${ }^{\circ} 54$.

412. «... instituyo Cristobal Ruiz de Manzanares, clerigo vecino de esta villa habra seis años y le dejo de renta quinientos ducados en cada un año, los cuales se distribuyen y gastan en ciertas misas que se dicen en una capilla que dejo en la iglesia mayor de esta villa y en dar veinte y cinco ducados cada año a un estudiante de su linage para que estudie y si se graduare sin tener prevenda le den cincuenta ducados y lo demas en casar huerfanas y dar limosnas a personas de su linage», n. ${ }^{\circ} 54$.

413. «... fundo Juan Ruiz de Bartholome Ruiz vecino de esta villa habra dos años y dexo cuarenta mil maravedis de renta para casar huerfanas de su linage», $n .^{\circ} 54$.

414. «... patronazgos pequeños, que han dejado vecinos de esta villa», n. ${ }^{\circ} 54$. 


\section{Pueblo}

Membrilla
Obras pías, patronatos, fundaciones, etc. Cuantía Dedicación

$-20.000 \mathrm{mrs}$.

- Casamiento de doncellas ${ }^{415}$

-200 duc.

- Limosnas y cura que enseñe catecismo $^{416}$

- ? especie

$-40 \mathrm{rs}$.

$-12 \delta 13.000$ duc.

$-13.000 \mathrm{mrs}$.

$-10.000 \mathrm{mrs}$.

$-4.000 \mathrm{mrs}$.
- Ayuda a campesinos necesitados ${ }^{417}$

- Sufragios ${ }^{417}$

- Pósito, casamiento y sufragios ${ }^{418}$

- Casamiento y limosnas ${ }^{419}$

- Limosnas ${ }^{420}$

- Limosnas y sufragios ${ }^{421}$

415. «... dejo Gonzalo de Rios, vecino desta villa (...) veinte mil maravedis de renta de censos al quitar en cada un año para casar dos doncellas huerfanas de su linaje, es patrono el concejon, n. ${ }^{\circ} 54$.

416. «... dejo Hernando Martin Crespo y su muger (...) vale doscientos ducados de renta en censos al quitar y tierras y desto se da al dicho trigo a los cuatro pobres y cinco mil maravedis al capellan porque enseñe la doctrina a los niños por cada año (...) actualmente el Licenciado Pedro Lopez Trompo con cargo de cinco misas cada semanan, $n .^{\circ} 54$.

417. «... hay un posito de trigo que dejo Mino Gutierrez, vecino desta villa que hoy tiene mil y ochocientas y veinte y seis fanegas de trigo las cuales dejo para que el concejo como patrono las reparta en los vecinos desta villa prestadas para sembrar y proveer sus necesidades o dallo en pan cocido en tiempos de necesidad; asimismo dejo cuarenta reales en cada un año para que se diga una misa cada semana», n. ${ }^{\circ} 54$.

418. «... un patronazgo que dejo Hernando Ruiz Cacho que vale doce o trece mil ducados para hacer un posito de tres mil fanegas de trigo y para dar en casamiento a sus deudas y decir ciertas misas, lo cual dejo a la voluntad del patrono que es de presente Pedro Camito, el cual dicho patronazgo esta en censos al quitar y en tierras que se arriendan, valen los censos en cada un año setecientos ducados y tresceintas fanegas de trigo de renta de las tierras unos años mas y otros menos y unas casas en que se recoge el pan del dicho posito y los aposentos de abajo se alquilan y el dicho pan se ha de dar a sus deudos dos reales menos en cada fanega de lo que valiere en tiempo de necesidad», n. ${ }^{\circ} 54$.

419. «... un patronazgo que dejo Gonzalo Garcia de los Mozos para que se diese de limsona a sus deudos para ayudar a sus casamientos trece mil maravedis en cada un año el cual rento esta en censos al quitar», n. ${ }^{\circ} 54$.

420. «... dejo Juan Lopez Rabel y su muger y Pero Lopez su hijo, diez mil maravedis de renta en cada un año para que el concejo los de de limosna a personas de necesidad vecinos desta villa la Semana Santa, esta en censos al quitar», n. ${ }^{\circ} 54$.

421. «... hay mas cuatro mil maravedis de renta en censos al quitar que dejo Alonso Garcia Redondo, los dos mil y seiscientos para que le digan una misa cada semana y lo demas a povres, dalo el concejo y es patron y pone capellan», n. ${ }^{\circ} 54$. 
Pueblo

Puertollano

\section{Obras pias, patronatos, fundaciones, etc. Cuantía Dedicación}

- Ropa para pobres ${ }^{422}$

- 20.000 mrs. - Ropa, pan y comida a pobres ${ }^{423}$

- 6.000 mrs. - Casamiento ${ }^{424}$

- 8.571 mrs. - Casamiento ${ }^{425}$

- 60 duc." - Casamiento ${ }^{426}$

- $20+10$ duc. - Casamiento ${ }^{426}$

- ? (limosnas) - Limosnas a los pobres ${ }^{427}$

- 6.000 mrs. - Predicador de la Cuaresma ${ }^{428}$

Torre de J. Abad, La - 23 duc: - Ropa para pobres ${ }^{429}$

- 13 duc. - Limosnas 430

Viso del Marqués $\quad-12.000 \mathrm{mrs}$. - Casamiento y estudios ${ }^{430 b i s}$

422. «... don Sancho Cabrero, Comendador que fue desta villa dejo de renta en cada un año para que se echen en ropa para pobres y se les de cada año y asi se les da ... maravedis», n. ${ }^{0} 54$.

423. «... Gonzalo Vazquez vecino que fue desta villa dejo veinte mil maravedis de renta en cada un año los diez mil que se den a pobres en vestidos de paño y lienzo en la Pascua del Santisimo Nacimiento de nuestro Señor Jesu Christo y los otros diez mil maravedis que se den en pan y comida a los pobres el dia de Pascua de Resurreccion de cada un año y asi se dan», n. ${ }^{\circ} 54$.

424. «... Anton Sanchez Largo, dejo seis mil maravedis de renta en cada un año que se den de limosna a una parroquia suya para su casamiento", $n .^{\circ} 54$.

425. «... Francisco de Mora, vecino desta villa dejo ocho mil y quinientos y sesenta y un maravedis de renta en cada año para dar en casamiento a doncellas pobres asi de su linage como del linage de sus mugeres", n. ${ }^{\circ} 54$.

426. «... hay mas una cofradia o hermandad que se dice de las Doncellas, la cual dicha cofradia da cada un año sesenta ducados a dos doncellas treinta ducados a cada una para ayuda a su casamiento siendo naturales desta villa y pobres y de buena fama y mas en esta dicha cofradia dejo el dicho Gonzalo Vazquez veinte ducados de renta para ayudar a casar otra doncella y la dicha cofradia de otros diez ducados para dar treinta a otra doncella y asi llevan todas tres a treinta ducados cada una", $n .^{\circ} 54$.

427. «... hay una cofradia de la Concepcion de Nuestra Señora que se nombran cuatro diputados que pidan limosna por el pueblo y a todo lo que llegan de limosna lo reparten en los pobres del pueblo», n. ${ }^{\circ} 54$.

428. «... el dicho GonzaloVazquez dejo seis mil maravedis de renta para ayuda el salario o limosna que se da a el Predicador de la Cuaresma», n. ${ }^{\circ} 54$.

429. «... veinte y tres ducados en paño para vestir a los pobres que dejo los diez doña Maria Bernal y la de Pedro de Sanchez del Pino», n. ${ }^{\circ} 54$.

430. «... otros diez y tres ducados Pedro de Guatas y se reparten», n. ${ }^{\circ} 54$.

430 bis. «Juan Sanchez de Valdepeñas vecino que fue desta villa dejo ciertos censos al tiempo que murio y se vendieron y los maravedis dellos se pudieron a renta y mando que los maravedis que en cada un año rentasen que son doze mil maravedis poco mas o menos se diesen para casar huerfanas y pobres de su linaje y para que estudiasen así mismo pobres del dicho linaje y en esto se an gastado y gastan y dello somos así informados», $n .^{\circ} 54$. 
Obras pías, patronazgos y fundaciones (resumen):

$-\mathrm{N} .^{\circ}$ de obras pías y/o fundaciones: 28 , repartidas entre 7 pueblos.

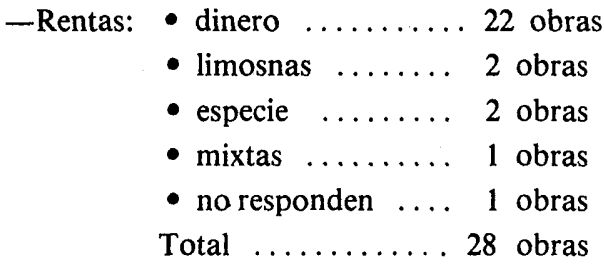

- Renta en dinero: 6.917.681 a 7.292.681 mrs. aproximadamente, porque una de las obras no responde la cuantía de la renta y otras dos se sustentan por medio de colectas públicas y es imposible en absoluto calcular el valor de la cuantía.

- Renta en especie:

- casas $\ldots \ldots \ldots \ldots \ldots \ldots$ varias
- huertas $\ldots \ldots \ldots \ldots \ldots \ldots .61$
- fanegas de tierra $\ldots \ldots \ldots .600$
- fanegas de frutos $\ldots \ldots \ldots 2.126$

- La media aproximativa por obra pía y/o fundación es de 247.060,03 a 260.452,89 mrs. más 21,4 fan. de sembradura y 75,9 fan. de fruto, sin contar las casas y la huerta.

- Cargas de las obras pias y/o fundaciones:

- se dedicarán a casamiento $\ldots \ldots \ldots \ldots \ldots \ldots . \ldots 13$

- se dedicarán a limosnas $\ldots . \ldots \ldots \ldots \ldots \ldots . \ldots 7$

- se dedicarán a sufragios $\ldots \ldots \ldots \ldots \ldots \ldots \ldots 6$

- se dedicarán a ropa y comida a pobres $\ldots \ldots \ldots .44$

- se dedicarán a estudio-enseñanza $\ldots . \ldots \ldots \ldots \ldots . . \ldots$

- se dedicarán a predicador $\ldots . . . \ldots \ldots \ldots \ldots .1$

- se dedicarán a fin desconocido $\ldots . . \ldots \ldots \ldots \ldots, 1$ 


\section{Pueblo}

Almodóvar del Campo

Calzada de Calatrava

Campo de Criptana

Castellar de Santiago

Fuencaliente

Puertollano

Tirteafuera

Valenzuela de Calatrava

\section{Reliquias ${ }^{431}$}

Cabeza Extremidad. Huesos L. Crucis Otras Objetos

$\mathrm{x}$

$\mathbf{x}$

$\mathbf{X}$

$\mathbf{X}$

$\mathbf{x}$

$\mathbf{x}$

$\mathbf{x}$

$\mathbf{x}$

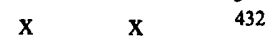

433

434

435

436

$x^{437}$

438

$\mathrm{x}^{439}$

431. El tema de las reliquias, origen, devoción, uso, adquisición, etc. se puede prestar a polémica; no olvidamos que durante siglos fue un arma de gran poder espiritual, religioso y atractivo con resabios mágico-supersticioso. Difícilmente podemos decir en qué sentido y con qué valor las toman en estos pueblos. Por el texto parece que le tienen respeto; también hemos visto que por tener una reliquia son capaces de hacer fiesta y voto (Castellas de Santiago, cfr., nota 312).

No nos extraña que sean tan pocos los pueblos que responde, porque es un tema que necesita la coincidencia de varios aspectos - un hijo del pueblo con cargo civil, militar o eclesiástico de cierta envergadura, con posibilidad de largos viajes por lugares remotos y de cierta piedad y cariño al pueblo para dedicarse a recoger estas reliquias- que lo hagan posible.

La autenticidad de estas reliquias - y de todas - no queda garantizada porque exista una bula, certificado o documento sellado y firmado que lo muestre. Sabemos que con estos requisitos han salido más de dos espuertas con muelas de Sta. Polonia, muchas más cabezas de once mil de las vírgenes, casi un calvario de cruces, piedras, tierra, palos, etc. de lugares sagrados para construir pueblos enteros...

Es un aspecto más de la vivencia religiosa popular en Castilla la Nueva y nosotros recogemos, catalogamos y estudiamos las respuestas.

432. «En esta dicha iglesia hay una caja de reliquias santas de diversos santos que trajo y dono a ella un Padre sacerdote natural desta villa que se llamaba Juan Fernandez, Capellan que fue de Su Majestad en su real corte y despues fue muerto y segun dicen martirizado en un lugar del Alpujarra en el revelion pasado que tuvieron los moros en Granada, esta la dicha caja de reliquias en una ventana o alacena junto al altar mayor a la parte de la Epistola: hay entre ellas un pedacito del Lignum Crucis de Nuestro Redentor engastada en una cruz de oro, hay cabeza de una de las once mil vírgenes; hay huesos de algunos de los Apostoles y otros santos que tienen sus rotulos y sus creaciones y de todo hay verdadero testimonio y se tienen en mucha veneración y se sacan los dias de Corpus Christi a la procesion y otros dias principales tienen la caja sus tres llaves», $n .^{\circ} 51$.

433. «... en la iglesia mayor de esta villa esta un pedazo de hueso de un dedo de señora Santa Quiteria, segun se dice y esto se responde», $n .^{\circ} 51$.

434. «Hay una reliquia notable en una cruz de oro y un pedazo de Linum Crucis, tienese en grande veneracion y devocion en esta villa porque se tiene por muy cierto de que viene tempestad de piedra que jamas sacando la Cruz apedrea en este termino", n. ${ }^{\circ} 51$.

435. «... esta una reliquia y hueso de señor San Benito», n. ${ }^{\circ} 52$.

436. «En la iglesia parroquial de la dicha villa hay una reliquia, conviene a saber: una cabeza de una de las once mil virgenes, en la cual se tiene mucha veneracion, la cual algunas fiestas principales del año se muestra al pueblo y todos tocan en ella las cabezas, ojos, y bocas y cuencas y otras cosas por devocion", $n .^{\circ} 51$.

437. «... a la dicha ermita (de Ntra. Sra. de Gracia) trujo un Juan Fernandez, clerigo presbitero, capellan que fue del Emperador nuestro Señor, y Canonigo que fue de Ujijar del Alpujarra, el cual murio martirizado por los moros del reino de Granada cuando se alzaron y rebelaron 
Desglosadas, tenemos:

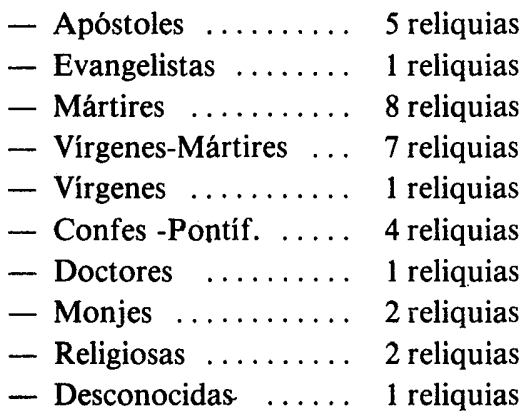

Sin catalogar $\ldots \ldots 15$ reliquias
- N. ${ }^{\circ}$ de pueblos con reliquias: 8

- N. ${ }^{\circ}$ de reliquias:

- huesos .....47

- objetos ..... 13

Total ..... 60

- Corresponden a 7,5 reliquias/pueblo.

(y otras)

(y otras)

con los demas que alli murieron, era natural desta villa y de la villa de Almodovar ciertas reliquias de Santos de partes ultramarinas que son las que se siguen (véase nota 432): en una caxa de tres tablas la cual enmedio tiene un Anus Die con sus reliquias; demas desto hay un hueso da Santiago, otro de Santa Maria Magdalena; otro de santa Caterina; otro de Santo Matia; otro de San Guandelino; otro de San Leopoldo; otro de santa Barbara; otro de Santa Guandelina; otro de San Jorge; otro de San Ulrico, Obíspo; otro de San Christobal; otro de San Nicasio xoto magense, Obispo; otros once huesos de Santos en las tablas colaterales sin titulos que son por todas las reliquias de esta casa treinta, hay otro segundo relicario redondo como espejo que tiene las reliquias siguientes: un hueso de San Laurencio, otros de San Andres, otro de Santa Ines en medio San Jeronimo cercado con otras muchas reliquias; en otro tercero relicario de cuatro esquinas hay una cabeza de las once mil virgenes, un hueso de Santa Margarita, otro de San Bonifacio un poco de tierra del Campo Damasceno adonde fue criado Adan; una canilla de San Eustaquio; una partecita de la Santisima Cruz; otra reliquia de la piedra donde fue coronado Nuestro Señor Jesuchristo, otra parte de la piedra adonde Jesuchristo oro en el Huerto, dos cuentas pequeñas de la madera del Monte Olivete, un hueso de San Mateo; otro de San Pablo; otro de San Anton Abad; otro de Santa Rebena; otro de Santo Sebastian, un poco de tierra adonde estuvo reclinado el mismo Jesus la noche de su Santisimo Nacimiento, un hueso de Santa Felicula, otro de San Christobal, otro de Santa Ursula, otro pedazo de las piedras adonde encajaron la Santa Cruz del Monte Calvario, unos cabellos de una Santa, un casco de Santa Befa, otras muchas reliquias se contienen en el cofre, las cuales no se sabe de que santos o santas sean ansi que por algunas traen titulos en lengua estranjera, como porque otras no traen titulo ninguno, recibieronse en la dicha villa a cuatro dias del mes de junio de mil quinientos y cincuenta y siete años, todas las dichas reliquias se trujeron y presentaron en la dicha ermita con dos titulos escritos en pergamino con sus sellos pendientes, el uno dado por el Cardenal de Santo Angel llamado Reinuacio y el otro por el Obispo Ferrense Delegado de Su Santidad, por los cuales dichos titulos parece y se manda tener y reverenciar las dos reliquias por santas y ciertas y verdaderas, conforme a la declaracion y nombre dellas», $n .{ }^{\circ} 51$.

438. «... hay una reliquia que se dice del Lignum Crucis», n. ${ }^{\circ} 51$.

439. «... en la iglesia desta villa en el Sagrario hay una caxuela pequeña que dentro della tienen unas reliquias que dicen ser un hueso de San Martin y un pedazo del habito de Fray Diego y otras que no saben los nombres», n. ${ }^{\circ} 51$. 


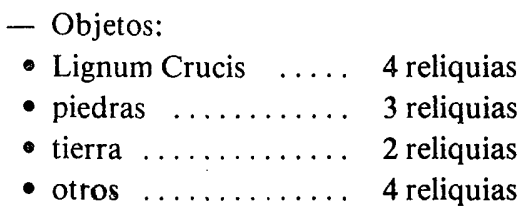

\section{Pueblo}

Almodóvar del Campo

Ballesteros de Calatrava

Cabezarados

\author{
Milagros 440 \\ - Plaga disuelta 44 I \\ - Tullido que anda ${ }^{442}$ \\ - Quebrado que anda ${ }^{443}$ \\ - Tepestad que no hace daño ${ }^{444}$
}

440. Enjuiciar un milagro excede a nuestra capacidad y pretensiones, aunque reseñamos aquellos hechos que como «milagros» son tomados y descritos en las Relaciones. No entramos en la valoración objetiva y afinidad que estas narraciones y sus contenidos puedan tener con «aquello que ha sido hecho por Dios fuera del orden de toda naturaleza creada», (Summa Theol., I, q. $110, a, 4)$.

No conocemos ningún relato que nos lo refieran sus propios protagonistas. Creemos personalmente que lo descrito en las Relaciones se trata de hechos desacostumbrados, poco frecuentes, etc., pero difícilmente entran en el orden extranatural. Por otra parte, hechos con causas totalmente explicables puede ser, para una mente ignorante, un portento; si por medio anda la religión y, además, hace tiempo, se convierte en milagro.

No se nos escapa la posibilidad pedagógico-catequética que estas narraciones y comentarios podian tener para no enfriar la piedad o reactivar el fervor religioso. En cualquier caso, nosotros, aquí también, recogemos, catalogamos y estudiamos las respuestas.

441. «... en los años de cuarenta y cinco y cuarenta y seis sobre mil y quinientos permitio Nuestro Señor que sobreviniese a toda esta tierra y talase y destruyese los panes (la langosta), envio esta villa un propio al reino de Navarra a un lugar del a do dicen estar en cuerpo del Bienaventurado Santo (S. Gregorio Nacianceno) y de alla trajo agua que se aspergio en los campos y fue Dios servido que se alzase la plaga de la langosta», n: ${ }^{\circ} 52$.

442. «... un Bartholome de Luna vecino de esta villa estaba tullido y fue a su casa bendita (ermita de Ntra. Sra. de la Paz) con dos muletas y se las dexo alla y vino sano", $n .^{\circ} 51$.

443. «Este año pasado de mil y quinientos y sesenta y cuatro años un hijo de un Alonso Sanchez vecino de esta villa estaba quebrado de ambas bedijas y los llevaron aquella bendita casa (ermita de Ntra. Sra. de la Paz) y lo truxeron sano aquel mismo dia y esta sano al presente», $\mathbf{n} .^{\circ}$ 51.

444. «... habra cuatro años un dia despues de la dicha fiesta (Cruz de Mayo) se apedrearon los panes e vir̃as deste pueblo y el pueblo e gente del se vio en mucha necesidad e aprieto porque fue tanta el agua y piedra que cayo que fuera de destruir los panes pensaron todos ser anegados en sus casas y muchos vecinos se fueron corriendo a la iglesia a se recoger y favorecer y sucedio que los trigos que quedaron por el suelo dentro de cuarenta dias poco mas o menos volvieron a nascer de manera que se cogio algun trigo e se tuvo a milagro el tornar a nascer e granar en tan breve tiempo», n. ${ }^{\circ} 52$. 
Pueblo

Campo de Criptana

Chillón

Daimiel

\section{Milagros}

- Tullido que anda ${ }^{445}$

- Un niño abre una enorme puerta ${ }^{446}$

- Rogativa escuchada ${ }^{447}$

- Aparición de la Virgen ${ }^{448}$

445. «... en la ermita de la Señora de Criptana un cuarto de legua desta villa tienen los vecinos y comarcanos gran devocion en ella que ha hecho milagros conocidos porque una hija de un doctor Sigura medico desta villa habia estado mas de un año en la cama que no se meneaba ni hablaba, llevaronla a tener novenas a la ermita de la Senora de Criptana y metieronla en un colchon a la ermita entre tres o cuatro y dejaronla cerca del altar y volvieron a meter en el gato del carro y des que entraron en la ermita estaba incada de rodillas en el altar de Nuestra Señora, dando gracias a Dios y a su Santa Madre», $n .^{\circ} 51$.

446. «... yendo dos clerigos que son vivos, vecinos desta villa a decir misa un sabado y con ellos gente a la ermita de la Señora de Criptana y estaba cerrada con una llave de loba e iba alli el mayordomo y no sabian de la llave y probaron de abrir la dicha ermita repujando la puerta des que vieron que no podian abrir, habia una red de palo al cabo de la ermita para que desde alli rezaren a la imagen de Nuestra Señora de que estuviese cerrada enviaron a una huerta por una mesa y lumbre porque estaba cerca para decir misa debajo de un portal que habia allí porque llevaron aparejo para decir misa y en el entretanto un niño que iba alli llego a las puertas y en tocando en ellas se abrieron entrambas y entraron y dixeron misas», $n .^{\circ} 51$.

447. «... hay una ermita en una alta sierra que se dice Nuestra Señora del Castillo donde esta una imagen de bulto de Nuestra Señora muy devota (...) y acuden a pedir remedio de sus necesidades y ansi se dice de muchos enfermos de enfermedades y lesiones a esta Santa Señora y sanan y en necesidades de agua hemos visto y vimos que el mes de abril de mil y quinientos y sesenta y seis habia gran necesidad de agua en este pueblo y se habia en el hecho muchas procesiones a las ermitas de alrededor del dicho pueblo (...) y viendo la sequedad del pueblo y que todo se perdia por ser como era ya en el mes de abril acordaron de ir en procesion casi toda la gente deste pueblo una mañana en que iba mucho numero de hombres e mujeres y niños y algunos hermanos de la Santa Vera Cruz y se iban disciplinando y toda esta gente junta con la clerecia partieron con gran serenidad desta villa y estando alla celebraron misa e predicaron y partieron de alla para venir a esta villa y plugo a Nuestro Señor por intercesion desta Santa Señora Madre suya de enviar tanta plubia de agua que toda la gente se mojo y venia muy a la lijera porque los caminos venian hechos rios y ansi todo este pueblo tuvo por cosa muy cierta que esta misericordia y otras muchas se han hecho en remedio de las necesidades deste pueblo son por intercesion desta Santa Señora», n. ${ }^{\circ} 40$.

448. «... la fundación della (ermita de Ntra. Sra. de la Paz) fue esta manera: que una niña que fue mujer despues de un vecino desta villa que se llamo Pero Sanchez Mohino, que se llamo ella Ana Hernandez, dixo que se habia aparescido Nuestra Señora un dia de Sant Bernabe que en esta villa se corrian toros y ella estaba guardando una parva de su padre e que le dixo que dixese en el pueblo que hiciesen alli una ermita y que la llamasen Nuestra Señora de la Paz y que cesaria la muerte de la gentes; y que la niña respondio que no la creerian y que Nuestra Señora le dixo que hiciesen en aquel sitio un pozo y que hallarian un ladrillo colorado dentro e que por aquellas señas la creerian; y que la niña lo dixo en el pueblo y que se hizo el pozo que agora esta cerca de la dicha ermita a la Puerta del Sol, e que habian hallado el ladrillo e que ansi se edifico la dicha ermita y esto ha sido cosa muy publica», $n .^{\circ} 51$. Más abajo viene el relato de la aparición y construcción de la ermita en verso romanceado y un villancico, «fecho en metro por un devoto de su sancta casa en el año del señor de mil y quinientos y sesenta», cfr. $n .^{\circ} 51$. 
Pueblo

Fuencaliente
Milagros

- Robo castigado ${ }^{449}$

- Lisiados, cojos y mancos que sanan ${ }^{450}$

- Aparición de la imagen de la Virgen ${ }^{451}$

- Muerte por falta de fe ${ }^{452}$

- Ungüento que cura ${ }^{453}$

449. «... un dia un hombre forastero que pasaba por esta villa hurto de la iglesia de ella un acetre y yendo el dicho hombre camino de Almodovar y habiendose echado de menos el dicho acetre y con sospecha que el dicho hombre lo llevase la Justicia envio tras el para ver si lo llevaba y habiendo sentido e visto el. dicho hombre antes que a el llegasen la justicia, se aparto del camino y en una mata escondio el acetre.y se torno al dicho camino y llegada la gente de la justicia le dijeron que si llevaba el dicho acetre, el cual con juramento dijo que no lo llevaba al dicho acetre, que si que era verdad, que se lo traia dijo: por la gracia de Dios que si tal traigo que de malos lobos sea comido y que con esto lo dejaron y la gente se volvio y que viniendose a poco rato oyeron voces a la parte donde el dicho hombre habian delado y volvieron a ver que era y hallaron la cabeza y los huesos del dicho hombre metidos dentro en el dicho acetre que estaba escondido en la dicha mata del monte, el cual dicho acetre y huesos y cabeza truxeron a la dicha villa de La Fuencaliente», $n .^{\circ}$ 37.

450. «... la imagen de Nuestra Señora que esta en la iglesia de la dicha villa, es de muy grande devocion y principalmente en otros tiempos se mostraban muchos milagros y concurrian en romeria a la dicha imagen (...) el dia de Nuestra Señora de septiembre (...) y tienese por cierto que aquel dia concurrian en romeria tanta gente que la limosna que la gente daba aquel dia valia trescientos ducados y cien mil maravedis, porque veian muchos milagros que Nuestra Señora mostraba en los lisiados y cojos y mancos y asi de presente hay devocion, aunque parece que se ha resfriado algun tanto», n. ${ }^{\circ} 46$.

451. «... en la iglesia mayor de la dicha villa, en donde esta la imagen de Nuestra Señora (...) esta una fuente de agua muy caliente de su natural de agua, de la cual, va por una acequia encañada y por medio de la dicha iglesia y va a dar a los baños que estan por debajo de la dicha iglesia junto a la cual dicha fuente es comun opinion que se aparecio la dicha imagen de nuestra señora antes que el pueblo se fundase (...) por los muchos milagros que hacia, dio causa que el dicho lugar se poblase de gente», n. ${ }^{\circ} 51$.

452. «... una mujer vino en romeria a la dicha iglesia y con ella traia una mocita hija suya y que desnuda la mocita hija suya para la meter a labar y bañar en la dicha fuente, las personas que se hallaron alli le decian: buena mujer mira que es la fuente de Nuestra Señora y donde ella se aparecio, no querais vos meter en ella vuestra hija, y la dicha mujer porfiando que la habia de meter en la dicha fuente dijo anda que tambien mi hija es virgen y donzella y diciendo esto la metio dentro de la dicha fuente y la mocita se fundio y la madre queriendola valerse quedo con los cabellos de su hija en las manós, los cuales cabellos han estado hasta agora en nuestros tiempos en la dicha iglesia en lugar principal y ansi lo estuvieron hasta que por tiempo se vinieron a gastar y consumir y muchas personas de las que de presente viven y conocieron los dichos cabellos», n. ${ }^{\circ} 51$.

453. «... en el agua caliente de la dicha fúente se hace y cria ungüento que le llaman las gentes y por devocion ungüento, y es de color amarillo el guerpo y las gentes que vienen en romeria ansi el dia de Nuestra Señora de Setiembre como otros tiempos del año cogen en botes el dicho ungüento, con el cual untan las partes en donde sienten dolores, y confiados de la misericordia de Dios Nuestro Señor y de su gloriosa y bendita Madre la Virgen Maria y con devocion que se tiene en el dicho ungüento, por ser y salir de la dicha fuente de Nuestra Señora y de un lugar tan virtuoso, muchos han rescibido sanidad y mejoria en sus enfermedades y dolores y lisiones de sus cuerpos y el ansi se ha visto y se ve por la misericordia de Jesu-Christo ser y pasar e pasa, ansi que en el dicho lugar agora en nuestro tiempo una mujer de vecino pario en dos veces dos criaturas, las 
Pueblo

Fuencaliente

Luciana

Manzanares

\section{Milagros}

- Resurrección de un joven ${ }^{454}$

- Hundimiento de la iglesia sin afectar a la Virgen ${ }^{455}$

- Cojo que anda ${ }^{456}$

- Aparición de una imagen y resurrección de una joven ${ }^{457}$

- Incendio de la iglesia que no daña al sacramento ${ }^{458}$

cuales salieron quebradas de ambas vidizas, y esta mujer encomendose a Nuestra Señora que se los sanase y untandoles aquellas partes con el dicho ung̈uento han sanado, y estan y viven sanos en desde el punto y hora que los untaron con el dicho ungüento, y esto es cierto, porque se ha visto estos dos milagros por los que agora viven», $n .^{\circ} 51$.

454. «... paresce por cierto e notorio y por tal se certifica que en el dicho lugar se murio un hijo a una mujer natural del dicho lugar, y llevandole a enterrar a la dicha iglesia su madre a voces y con grandes gritos y llorando a la Señora de la Fuencaliente: «Madre de Dios, torname mi hijo vivo, que bien creo que lo podeis vos hacer", y teniendole junto a la sepultura para lo enterrar, su madre se aparto y se puso de rodillas delante de la imagen de Nuestra Señora, y a voces le rogo y suplico con mucho fervor le tornase vivo a su hijo, y en esto el hijo se levanto y se asento en las andas en donde lo llevaban a enterrar. Lo primero que dixo el difunto: Loado sea Dios y el temocion .... que doy, todo el tiempo que vivio con un poco de temblor como parlatico, y vivio despues mucho tiempo casado, y tuvo hijos, y se tuvo por buen cristiano, y porque vivio bien y cuerdamente, y esto es publico e notorio, porque viven muchas personas que le concscieron al dicho mozo despues del dicho milagro, que habra que acaescio ochenta año», $n .^{\circ} 51$.

455. «... vino a caerse la capilla del altar mayor, en donde estaba la imagen de Nuestra Señora, la cual dicha capilla se cayo y el haestial della, y todo cayo sobre la dicha imagen, que fue mucha tierra y madera y piedra, por manera que anduvo mucha gente dos dias quitando la tierra y madera, $y$ hallaron la dicha imagen entera y puesta derecha en el altar sin ninguna quiebra ni falta en la imagen ni en el Niño Jesus (...) y se hallaron los manteles y frontales y peanas del dicho altar todo hecho pedazos, que no fueron de provecho mas, porque estaban molidos y hechos pedacitos de la tierra y piedras e madera y tejas que se cayo sobre ello, y esto es publico y notorio a todo el pueblo, porque habra que acontescio lo susodicho treinta años o antes menos que mas», $n .^{\circ} 51$.

456. «... habra veinte años que vino un hombre tullido, coxo con unas muletas a la dicha iglesia, en donde entro dando voces y llamando a Nuestra Señora de la Fuencaliente que tuviese por bien de sanarle de aquella lision, pues ella lo podia muy bien hacer, e luego el dicho hombre solto las muletas, y se tuvo en pie, y començo andar, y quedo saño y libre, y dio gracias a Nuestro Señor y a su Madre bendita por ello, y prometio de le traer para ella y el Niño Jesus dos coronas de plata, y ansi tardo dos años en se las traer, porque las pidio por limosna, y se las truxo, que son las que de presente tiene», $n .^{\circ} 51$.

457. «... hay una imagen muy devota que se llama Santa Maria Egipciaca, la cual imagen dicen los antiguos que se aparecio con una campanilla que ansimismo esta en esta iglesia en unas barrangras do se junta Guadiana y Bullaque y lo que oimos decir a los pasados y se tiene por cosa muy cierta que antes que esta villa se poblase la llevaron a esta imagen a Piedrabuena en procesion dos veces para tenella en su iglesia y que la tornaban a hallar a do se habia aparecido y que esta imagen ha hecho muchos milagros en esta villa y su comarca entre los cuales en la villa de Avenoja fallecio una moza y sus padres la ofrecieron a esta santa y la trajeron amortajada a esta iglesia y en asomando a esta villa resucito y esto se tiene por cosa muy cierta, porque se dice haber visto vecinos deste pueblo la mortaja», $\mathrm{n} .^{\circ} 51$.

458. «... y el milagro que fue Dios nuestro Señor servido de hacer en la quema que sucedio 
Pueblo

Membrilla

Montiel

\section{Milagros}

- Cojos que andan ${ }^{459}$

- Arrojan un niño a un pozo y se salva 460

- Aparición de la imagen de un Cristo ${ }^{461}$

en la iglesia mayor de la dicha villa el año pasado de setenta y uno y fue que otro dia de Corpus Christi, viernes a quince de junio del dicho año setenta y uno a las tres de la mañana, se hallo arder con la mayor furia que se puede decir el altar mayor de la dicha iglesia juntamente con los altares colaterales con muchos paños de oro y seda, piezas de plata y ornamentos que estaban colgados por ornato de la fiesta precedente alrededor del altar mayor y lo demas. Era tan grande el fuego que en mas de dos horas como se vio, no se pudo aunque con toda diligencia posible sacando agua de un pozo que tiene la dicha iglesia y de las casas mas cercanas apagar ni llegar sino de muy lexos al cavo de tres horas que consumio y quemo todo lo que pudo hasta los organos y escaños sin dexar señal de retablo ni otra cosa que con la mucha agua se pudieran matar las brasas y entrar hasta la parte del altar mayor con hartas lagrimas y solozos del pueblo se començo a desvolver los carbones y habiendo desvuelto gran pedazo, se hallaron algunas pastas derretidas de plata de custodia y calices y patenas que habian quedado en el altar mayor debaxo. De todo fue Nuestro Señor servido, que se hallo el relicario de plata donde habia quedado el Santisimo Sacramento, que era redondo, donde cabia la hostia de llano y de tres dedos de altura tan sano, limpio y entero comosino hubiera pasado el incendio dicho y dentro del se hallo el Santisimo Sacramento que habia quedado en sola una hostia y siete formas, algo tostadas, empero enteras y sanas las cuales comsumido luego un fraile agustino que se hallo en esta villa, adorandola la mayor parte del pueblo (...) consumieronse en esta quema mas de seis mil ducados», n. ${ }^{\circ} 37$.

459. «... hay una ermita de Nuestra Señora que esta en el castillo de Tocon de mucha devocion en esta villa y su comarca (...) y ha habido muchos milagros como ha sido venir coxos con muletas de palo y dejarlas alli yendo sanos y muchos bragueros de quebrados de como van sanos los niños», n. ${ }^{\circ} 51$.

460. «... habra dos años que habiendo parido ascondidamente una muger desta villa entre ella y el padre del nacido queriendo encubrir el parto y el nacimiento de un niño que pario, lo echaron en un pozo que esta en el dicho castillo donde esta la ermita de Nuestra Señora que tiene de hondo el dicho pozo diez y seis estados para que pereciese y se averiguo haber estado dos noches y dia y medio el dicho niño en el pozo sin mamar, ni antes haber mamado dende que nascio y ello fue milagro que Nuestra Señora hizo porque de ninguna manera se puede meter sino fue soltandolo dende arriba por la hondura y anchura que tiene lo cual se vino a entender por un hombre vecino de la Solana que se dice Alonso Diaz del Prado, que habiendo oido misa de alba se fue a visitar la ermita de Nuestra Señora y que le parecic que Nuestra Señora estaba mas resplandeciente que otras veces y salido de la dicha ermita subio a lo mas alto del castillo donde esta el dicho poço y oyo ruido a manera de criatura y no vido a nadie y ceso el ruido de la criatura y yendose a salir del dicho castillo torno a oir ruido y no vido cosa alguna y vino y dio noticia a Francisco Lopez Rael, su yerno, que al presente era alguaril en esta villa y le conto lo que habia visto y oido y los dos fueron y llegaron a la boca del pozo y sono la criatura dentro del pozo y dieron noticia a Juan de Daimiel, alcalde que de presente era el cual fue y llevo otras personas con el y metieron un hombre atado con sogas porque de otra manera no se puede entrar y el pozo estaba cerrado de telarañas a manera de no haber entrado en el cosa alguna y sacaron la dicha criatura y se salio riendo y esto y lo demas se tiene por milagro, vivio un año", $n .^{\circ} 51$.

461. «... hay una ermita de señor Santiago (...) y en una capilla de la dicha ermita esta un Crucifixo de un hombre de gran altura, el cual dicho Crucifijo, estan informados por cosa cierta que en el año de mil quinientos e veinte se aparescio en la dicha capilla donde agora esta en Cruz en un altar con mucha veneracion dia del Nascimiento de Nuestro Señor Jesuchristo del dicho año de veinte, el cual hizo muchos milagros cuando se aparescio e ha hecho despues aca», $n .^{\circ} 51$. 
Pueblo

Puertollano

Saceruela

Santa Cruz de Mudela

Terrinches

Torre de Juan Abad, La

Valenzuela de Calatrava

Viso del Marqués
Milagros

- Un enebro que mana aceite ${ }^{402}$

- Castigo por romper un voto ${ }^{463}$

- Elección de lugar para edificar una ermita 464

- Aparición de la imagen de la Virgen ${ }^{465}$

- Escuchan música y rezos en una ermita 466

- Roturas, sordos y mudos que sanan ${ }^{467}$

- Cera que arde sin consumirse en una ermita 468

- Sanan muchos quebrados 468 bis

462. «... otra ermita de Señora Santa Ana, a la cual dicen Santa Ana del Henebro, segun la publicidad antigua, poque junto a la dicha ermita dicen que antiguamente estaba un enebro el cual distilaba de si tanta cantidad de aceite cuando la lampara de la dicha ermita podia gastar ardiendo siempre de noche y de dia y hasta hoy hay en la dicha villa dos mogeres muy viejas, que dicen que se acuerdan (...) el dicho enebro que distilaba el dicho aceite se perdio y consumio porque estando un ermitaño en la dicha ermita vendio el aceite que se distilaba del y no encendia la lampara de la dicha ermita e asi ceso de distilar el dicho aceite, y las gentes lo arrancaron y se llevaron a pedazos de alli el dicho enebro», $\mathrm{n} .^{\circ} 51$.

463. «... otra ermita que se dice Nuestra Señora de Gracia (...) en la cual dicha ermita esta colgada una hoz de hierro de segar pan, la cual dicen que se puso alli por memoria de que yendo un hombre a segar con ella dia de la Visitacion de Nuestra Señora, que es la advocacion de la misma ermita y voto desta villa, a la primera hozada que dio en el pan se le torno la hoz hacia la mano y se la asio a ella de tal manera que no pudo segar ninguna cosa, lo cual afirman haber pasado asi personas ancianas, que dicen habello oido a sus padres y a otras muchas personas», $n .{ }^{\circ} 51$.

464. «... abajo del dicho pueblo casi a un cuarto de legua esta un sitio nombrado para ermita de señor San Gregorio Nacianceno el cual siempre que se ha echado suertes ha cabido a el este sitio"), n. ${ }^{\circ} 51$.

465. «... una imagen de Nuestra Señora pequeña, morena de rostro que de presente esta en ella (ermita de Nuestra Señora de las Virtudes), fue hallada y sacada de debaxo de tierra, dentro de unos edificios antiguos, en el sitio donde ahora esta la dicha ermita y por esta razon se edifico alli y hay tanta devocion a la dicha ermita de las gentes y que vemos y se ve claro sanar muchas personas de muchas y graves enfermedades que se encomiendan en Nuestra Señora de las Virtudes y van a visitar a su Santa casa», $n .^{\circ} 51$.

466. «... en esta ermita (de Ntra. Sra. de Luciana) han acontecido milagros de mucha devocion que se dice que el ochavario de san Francisco cuando murio la reina francesa se oian todo el ochavario musica como de que ofrecian visperas y tocan organo de que hobo grande admiracion y se tomo por testimonio», n. ${ }^{\circ} 51$.

467. «... hay una ermita que se llama Nuestra Señora de la Vega (...) e que se platica haberse fecho muchos milagros y que han sanado muchos de dolencias e quebracias de brazos y piernas y tetas y sordos y mudos y hay muestra de cera y piernas y brazos y otras cosas semejantes que se dejan los que sanan», n. $^{\circ} 51$.

468. (En la ermita de S. Agustín se dice a otro día de su fiesta). «... misa de Requiem por los difuntos, por los cuales oficios arden cantidad de cirios de cera que muchas personas llevan por devocion y en todo el tiempo que arden mientras se dicen los oficios no se gasta cera ninguna $y$ de esto se ha tomado muchas veces testimonio por ante escribano, dicen que se vivo a entender este milagro que faltando una vez el pioste y mayordomos la cera acostumbrada que solian llevar buscaron prestadas ciertos cirios para cumplir su fiesta y cuando los volvieron a sus dueños quiriendo yer lo que faltaba para se la pagar, no falto ninguna cera y desde entonces lo han esperimentado muchas veces y es cierto", $n .^{\circ} 51$.

468 bis. «... en la dicha ermita de señor Santo Andrés ha sido Dios Ntro. Señor servido que se ayan hecho numerosos milagros y an sanado muchos quebrados", $n .^{\circ} 51$. 
Resumen:

- Responden 18 pueblos con 30 portentos o hechos milagrosos:

- Fenómenos naturales $\ldots \ldots \ldots \ldots \ldots \ldots \ldots \ldots$

- Plagas disueltas .................. 1

- Apariciones ................... 5

- Curaciones diversas $\ldots \ldots \ldots \ldots \ldots \ldots \ldots . \ldots 9$

- Castigos ....................... 3

- Resurrecciones .................. 2

- Otros ...................... 8

Total 30

\begin{tabular}{|c|c|c|}
\hline Pueblo & Valor del diezmo ${ }^{469}$ & Quién lo cobra 470 \\
\hline Albadalejo & . 150 fan. & - La Mesa Maestral \\
\hline & .. 900 fan. & - El Comend. de Segura \\
\hline & $\begin{array}{l}\text { - Cebada } . . \\
\text { - Centeno }\end{array}$ & $\begin{array}{l}\text { - El Comend. de Segura } \\
\text { - El Comend. de Segura }\end{array}$ \\
\hline
\end{tabular}

469. No vamos a tratar del origen, significado y evolución de los diezmos. Era una carga onerosa más que tenía que soportar el agibiado labrador de unas tierras ingratas, con un sistema de producción inadecuado, con un utillaje arcaico y con una climatología hostil.

El diezmo es el $10 \%$ sobre las cosechas de cualquier tipo de productos; la lista sobre la que se aplicaba puede dejar perplejo al más curioso. Tomamos nota de los bienes sometidos a diezmo en las Relaciones de Villarrubia de los Ojos, cfr., n. ${ }^{\circ} 26$ (trigo, candeal, centeno, cebada, ganado de lana, lana, ganado cabrío, cáñamo, lechones, pollos, huertas, armaque, montaracia, vino, seda, aceitunas, azafrán, lino, mozos, becerros, pan de sereños y ganaderos, enjambres, teja, cal, ladrillos, guertos, guertas, navares, ajos, melones).

Muchas veces solo se citan y especifican los diezmos mayores y universales en esta tierra -cereal, vino, aceite; ganado- mientras que el resto se engloba en los llamados diezmos «menudos» o minucias. Casi siempre el valor es taxativa y matemáticamente el $10 \%$-cfr. Relaciones de Daimiel, $n .^{\circ} 26$, nota $481-$, pero puede haber excepciones.

Hallar el valor exacto es bastante difícil porque en las respuestas no se ajustan a una misma medida, ni una misma unidad monetaria y, además, nos encontramos bastantes veces con el «mas o menos», «un año con otro», etc.; sí se pueden dar totales aproximativos, basándonos en las tarifas - precioso detalle - y precios de la época que hemos encontrado en unas cuantas Relaciones: Albadalejo, Almadén, Santa Cruz de Mudela, Villarrubia de los Ojos, o en el rendimiento: Puertollano y Terrinches.

El valor real del diezmo es algo totalmente fluctuante, como la realidad de la que depende. Los campesinos bien claro quieren dejar la cuestión cuando se lamentan de la tierra, del clima, de malas cosechas, etc. Veamos algunas muestras:

- «... las tierras que tienen no son de mucho pan llevar, porque algunas dellas son delgadas, tierras de calores y cansadas por tener esta villa muy poco termino», Albaladejo, $n .^{\circ} 26$.

- «... las tierras del termino desta villa son pobres por la mayor parte», $n .^{\circ} 26$.

- «... esta tierra es de labranza la mitad del termino porque la otra mitad es cerros y valles y que los mas de los cerros no se pueden labrar», Almedina, $n .^{\circ} 26$.

- «... a causa de ser poco el termino desta villa hay poca tierra de labor», Cañada de Calatrava, n. ${ }^{\circ} 26$. 
Pueblo Valor del diezmo

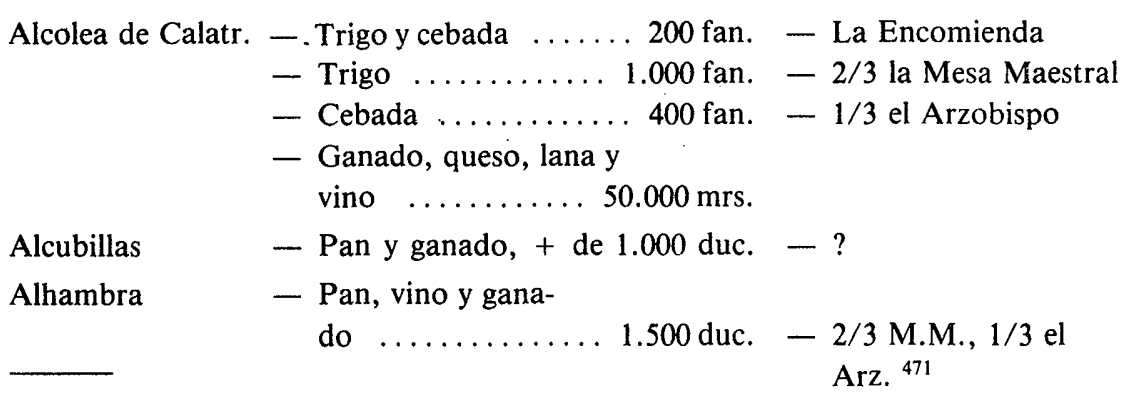

- «... y con ser mucha la gente traen muy cansadas las labores y no hay donde ensancharlias porque ya no hay donde romper de nuevo tierras ningunas», Daimiel, n. ${ }^{\circ} 26$.

- «... la tierra es muy fragosa y montosa y de mucho coste de labrar la tierra y desmontarla hasta la poner en disposicion de sembrarla", Fuencaliente, n. ${ }^{\circ} 26$.

- «... no es tierra de mucha labor que todo es rozas que cada año parecen que no hay tierras iabradas», Navalpino, n. ${ }^{\circ} 26$.

- «... es tierra de labor para pan aunque es poca respecto de la vecindad que hay porque es poca la labor y muchos los labradores», Piedrabuena, n. ${ }^{\circ} 26$.

-«... aunque se siembra se coge poco por los daños de los ganados monteses», Puebla de Don Rodrigo, $\mathrm{n} .{ }^{\circ} 26$.

- «... es tierra flaca y miserable», Saceruela, $n .{ }^{\circ} 26$.

- «... las tierras della no son de mucho llevar porque son las mas de ellas delgadas y cansadas y tiene muy poco termino esta villa», Terrinches, $\mathrm{n} .{ }^{\circ} 26$.

Por último, aquí también nos extraña la búsqueda del hispanista Salomón: mientras él afirma tener información de 55 pueblos - o.c., pág. 229- nosotros aportamos datos de 61 .

470. Siendo el diezmo un tributo netamente civil, por donaciones reales y señoriales -que en muchas ocasiones no pasaban de pretender comprar la limpieza de la vida presente y garantizar un lugar seguro para la futura - se fue transformando con ciertas interpretaciones forzadas a que la Iglesia también recibiera parte. El IV Concilio de Letrán lo impone como cosa obligatoria - cánones 53 y 54- con la protesta del poder civil. En más de una ocasión se acalló la protesta subiendo el tributo y así los Señores seguían percibiendo la misma cuantía; en otras, implicando a la corona que casi siempre estaba necesitando nuevas fuentes de ingresos para las merınadas arcas reales. En momentos de serios apuros y cuando el destino era combatir a los enemigos de la religión -el turco, el protestante, el judío... - la Iglesia generosamente cedía el cobro de ciertos diezmos integramente al rey para contribuir a una campaña en la que ella posiblemente sería la más fovorecida.

Ciertamente era un ingreso bastante sustancioso, como se puede ver; además, la división territorial de muchísimas archidiócesis se ha hecho - se hacía - en función de comarcas, zonas y pueblos «buenos» en sentido de ingresos y diezmos, y secundariamente por razones pastorales.

El Rey, el Arzobispo y los Señores, por este orden, son los destinatarios directos de estos ingresos. Muchas veces aparece el concepto de mesa Maestral -encomienda del maestre o de una ciudad o algo que le pertenece- - Una vez más hay que tener presente el hecho de que el administrador general de las Órdenes Militares es el rey, pero también es cierto que aún quedaban muchos privilegios y exenciones $-\mathrm{y}$ loas de tipo económico no escaseaban - que ostentaban personas y entidades particulares.

También podemos observar que la división $2 / 3$ y $1 / 3$ no es taxativa; a veces hay diezmos de productos que no entran en el reparto porque los lleva íntegramente el rey o señor, como puede verse en las Relaciones de Manzanares, $\mathrm{n}^{\circ}{ }^{\circ}$ 26, cfr. nota 484. 26.

471. «... e la decima dello al convento de Ucles de lo perteneciente a la Mesa Maestral», n. ${ }^{\circ}$ 
Pueblo

Almadén

Almedina

Almodóvar del C.

- Trigo

- Cebada

- Centeno

- Vino .........

- Queso, lana, ganado $\ldots \ldots \ldots$. $1.050 .000 \mathrm{mrs}$.

- Montaracia ..... $400.000 \mathrm{mrs}$.

Arenas de S. Juan

- Pan

6.000 fan

Argamas. de Alba

- Ganado 13 a 15.000 fan.

...... $320.000 \mathrm{mrs}$

- Vino ....... 20 a $30.000 \mathrm{mrs}$.

Argamas. de C.

- Trigo 2.000 fan

- Cebada

- Lana, ganado, mozos $1.000 \mathrm{fan}$. $300.000 \mathrm{mrs}$.

Arroba de los Montes 474

- Pan ... 120-130 a 1.500 fan. ${ }^{475}$ - ?

\section{Quién lo cobra}

600 fan. - ?

270 fan.

$180.000 \mathrm{mrs}$.

- El Comendador

- El Rey

- 2/3 el Rey; $1 / 3$ el

Arz. ${ }^{472}$
- El Rey y la Mesa M.

- ? ${ }^{473}$

- El Prior de S. Juan

- 2/3 el Rey; $1 / 3$ el Arz.

- Ganado .... 12 a $15.000 \mathrm{mrs}$.

472. «... y la primicia de todo este pan es y pertenece a la iglesia parroquial y a su obra y fabrica por la cual se cobra media hanega como la cosecha de cada vecino llegue a quince fanegas», n. 26.

473. «... del pan que se coge vale y cairan al dicho diezmo y tercio», $n .^{\circ} 26$.

474. Incluidos sus anejos.

475. Una de las mayores dificultades a la hora de interpretar las cifras del capítulo de los diezmos y su valor, es que en algunas Relaciones indican el valor real del diezmo entregado y en otras, el valor total de lo cosechado. Esta es una de las inexactitudes - que origina confusiónapreciadas en el profesor N. Salomón, que él aplica la reducción del diezmo sobre las cifras globales que indica el manuscrito y no avisa al lector de la operación efectuada. En este caso de Arroba está claro porque existen dos Relaciones de este pueblo que, bien analizadas, nos indican el valor aproximativo de las cifras que daba aquella gente y que, para ellos, eran exactas. También podemos apreciar el margen de diferencia de una a otra Relación, lo que nos indica que estamos ante unas apreciaciones verosimiles, pero nunca exactas. Las primeras cifras 120-130 fan. se refiere al diezmo; la segunda, 1.500 fan. se refiere a lo cosechado, cuyo diezmo sería de 150 fan. Cfr. Relaciones, $n .^{\circ} 26$ e introd., respectivamente. 
Pueblo

Valor dél diezmo

\section{Quién lo cobra}

\begin{tabular}{|c|c|c|}
\hline Ballest. de Calat. & $-\operatorname{Pan} \ldots \ldots \ldots$ & $-?$ \\
\hline Bolaños de Calat. & - Pan ......... 400 fan. 476 & $-?$ \\
\hline Cabezarados & $\begin{array}{l}\text { - Trigo, aprox. } \ldots \ldots \ldots 300 \mathrm{fan} . \\
\text { - Cebada } \ldots \ldots \ldots \ldots 200 \mathrm{fan} . \\
\text { - Centeno } \ldots \ldots \ldots \ldots 10 \mathrm{fan}^{477}\end{array}$ & $-?$ \\
\hline Calzada de Calat. & $\begin{array}{l}\text { - Trigo .......... } 1.500 \text { fan. } \\
\text { - Cebada ....... } 1.500 \text { fan. } \\
\text { - Ganado y lana .. } 600 \text { a } 700 \text { duc. }\end{array}$ & $-?$ \\
\hline Campo de Cript. & $\begin{array}{l}\text { - Pan } \ldots \ldots \ldots \text { 16 a } 18.000 \mathrm{fan} . \\
\text { - Vino ..... + de } 300.000 \mathrm{mrs} \\
\text { - Ganad.: corder. + de } 600.000 \mathrm{mrs}\end{array}$ & - El Rey y la Mesa M. \\
\hline Cañada de Calat. & $\begin{array}{l}\text { - Pan, aprox. } \ldots \ldots \ldots 600 \text { fan. } \\
\text { - Ganado } \ldots \ldots \ldots \ldots 600 \text { duc. }\end{array}$ & $-?$ \\
\hline Caracuel de Calat. & - Pan ........... 400 fan. & $-?$ \\
\hline Carrión de Calat. & $\begin{array}{l}\text { - Trigo } \ldots \ldots \ldots \ldots \quad 15.000 \mathrm{fan} . \\
\text { - Cebada } \ldots \ldots \ldots \ldots 2.300 \mathrm{fan} . \\
\text { - Vino } \ldots \ldots \ldots \ldots 100.000 \mathrm{mrs}\end{array}$ & - 2/3 Mesa M; 1/3 Arz. \\
\hline Castellar de Sant. & $\begin{array}{l}\text { - Trigo } \ldots \ldots \ldots \ldots 2.000 \text { fan. } \\
\text { - Cebada } \ldots \ldots \ldots \ldots 1.000 \text { fan. } \\
\text { - Vino } \ldots \ldots \ldots 2.000 \text { arr. }{ }^{478}\end{array}$ & $-?$ \\
\hline Castilseras & - Trigo y cebada ... & - La Encomienda \\
\hline Corral de Calat. & - Pan $\ldots \ldots \ldots \ldots 1.800$ fan. & $-?$ \\
\hline Cózar & - Trigo y cebada $\quad .2 .500-3.000$ fan. & - El Rey ${ }^{479}$ \\
\hline Daimiel &  & $\begin{array}{l}\text { - La Encom. de la Villa } \\
\text { - Villa }\end{array}$ \\
\hline
\end{tabular}

476. «... solia tener los años pasados dos mil fanegas de pan», . $^{\circ} 26$.

477. «... y esto un año con otro veinte y dos mil maravedis», $n .^{\circ} 26$.

478. «... se coge en cada año comunmente en esta villa veinte mil fanegas de trigo y diez mil de cebada y veinte mil arrobas de vino", $n .^{\circ} 26$. Es de suponer que habla de totalidad de la cosecha y no del valor de los diezmos que serían, respectivamente, $2.000,1.000$ y 2.000 , como nosotros anotamos.

479 «... los demás pueblos deste Campo de Montiel pagan terzuelo a el Arzobispo de Toledo y esta villa no lo paga, solamente lleva el Arzobispo veinte maravedis de visita de pila», $n .^{\circ} 2$. Aplicamos aquí también la reducción del deizmo, porque el manuscrito habla de «... se suelen coger en años moderados veinticinco mil fanegas de trigo e cebada o treinta mil fanegas», $\mathrm{n} .^{\circ} 26$.

480. Seguimos aplicando la reducción del deizmo; según el manuscrito lo que realmente recogieron fue: 40.000 fan. de trigo y candeal y 50.000 fan. de cebada y centeno, cfr. $n .{ }^{\circ} 26$.

481. Es curioso que cuando poco más abajo hablan de lo que se diezmó para la Encomien- 


\begin{tabular}{|c|c|c|}
\hline Pueblo & Valor del diezmo & Quién lo cobra \\
\hline Fernancaballero & - Trigo y ceb. . 2.000 a 2.500 fan. & $-?$ \\
\hline Fontanarejo & $\begin{array}{l}\text { - Pan, aprox. } \ldots \ldots \ldots 200 \mathrm{fan} . \\
\text { - Vino } \ldots \ldots \ldots \ldots 000 \mathrm{mrs} .\end{array}$ & $-?$ \\
\hline Fuencaliente &  & $-?$ \\
\hline Herencia & $\begin{array}{l}\text { - Pan ..... } 7.000 \text { fan. aprox. } \\
\text { - Ganado y vino } 200.000 \text { mrs. }\end{array}$ & $\begin{array}{l}\text { - 2/3 Prior S. Juan; } 1 / 3 \\
\text { el Arzobispo }\end{array}$ \\
\hline Horc. de los Mont. & - Pan $\ldots \ldots \ldots \ldots .500$ fan. ${ }^{482}$ & - Arzobispo, Rey, etc. \\
\hline Luciana & $\begin{array}{l}\text { - Trigo, aprox. } \ldots \ldots \ldots 200 \text { fan. } \\
\text { - Ceb. y cent. aprox. . } 100 \text { fan. }{ }^{483} \\
\text { - Ganado y uva } \ldots 20 \text { a } 25.000 \text { mrs. } \\
\text { - Cerdos } \ldots \ldots \ldots \ldots \ldots \ldots \text { ? }\end{array}$ & - El Señor de Piedrab. \\
\hline Malagón & $\begin{array}{l}\text { - Pan } \ldots \ldots \ldots \ldots \ldots 6.000 \mathrm{fan} . \\
\text { - Pan, vino, ganado } .160 .000 \mathrm{mrs} .\end{array}$ & \\
\hline Manzanares & 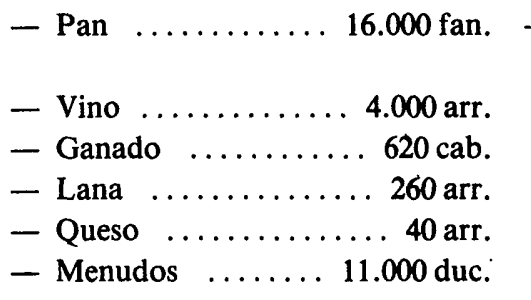 & $\begin{array}{l}\text { - 2/3 el Comendador; } \\
\text { 1/3 el Arzobispo }{ }^{484}\end{array}$ \\
\hline Membrilla & 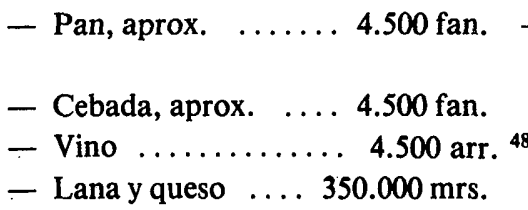 & $\begin{array}{l}\text { - 2/3 Mesa M.; } 1 / 3 \text { el } \\
\text { Arzobispo. }\end{array}$ \\
\hline
\end{tabular}

da de la villa, hagan la reducción: «... se cogieron quinientas fanegas de trigo, de que se dezmaron cincuenta y dos mil quinientas de cebada de que se dezmaron docientas y cincuenta fanegas», n. ${ }^{\circ} 26$.

482. «... se suele coxer en el dicho lugar como cinco mil fanegas de todo pan un año con otro, y que de alli viene el diezmo lo que le cabe a pagar, $n .{ }^{\circ} 26$. Nosotros aplicamos el deizmo y anotamos 500 fanegas.

483. «... el diezmo de pan se suele arreendar de cincuenta a setenta mil maravedis poco mas o menos», n. ${ }^{\circ} 26$.

484. «... lo que lleva el Arzobispo de Toledo no vale la tercia parte, porque el comendador desta villa tiene aprovechamiento de que el Arzobispo no lleva», n. ${ }^{\circ} 26$.

485. Incluimos el total de los diezmos - 2/3 de la Mesa M. y 1/3 del Arzobispo- aunque el manuscrito nos habla únicamente de los $2 / 3$ que entregan a la Mesa Maestral: «... de diezmo de pan que se diezma a la dicha Mesa Maestral tres mil fanegas de trigo y otras tantas de cebada poco más o menos (...) y de vino tres mil arrobas en cada un año poco mas o menos», $\mathrm{n}^{\circ}{ }^{\circ} 26$. No comprendemos por qué Salomón rehace la cifra del pan y de la cebada, pero no la del vino, cfr. Salomón, N., o.c., 476-477, y no avisa de la alteración que efectúa. 
Pueblo

Miguelturra

Valor del diezmo

- Pan 1.800 fan

- Vino $200.000 \mathrm{mrs}$

Montiel

Moratalaz ${ }^{488}$

- Trigo y cebada 800 fan

- Trigo y candeal ... 2.900 fan.

- Cebad. y cent. .. 1.600 fan. ${ }^{489}$

Navalpino

- Trigo y cebada

Navas de Estepa

- Pan

- Ganado

- Colmenas y lechones de 14 a $15.000 \mathrm{mrs}$.

Piedrabuena

- Pan ........ 3.000 fan. ${ }^{49}$

- Ganado $130.000 \mathrm{mrs}$.

\section{Quién lo cobra}

2/3 Maestre Ctrva.; 1/3

Arcediano Ctrava. ${ }^{486}$

- El Rey ${ }^{487}$

- El Comendador de Manzanares

- $2 / 3$ el Señor de la Villa; $1 / 3$ el Arzobispo

Pozuelos de

Ctrva., Los

- Trigo, cebada, centeno, aprox. .... 300 fan. - ?

- Ganado .... 15 a 20.000 mrs.

Puebla del Príncipe- Trigo .......... 200 fan. - El Rey

- Cebada y centeno ... 160 fan.

- Vino ............. 40 arr.

- Trigo ............ 50 fan.

- Cebada ........... 40 fan.

- Vino ........... 200 arr.

486. «... al dicho Maestre pertenecen los diezmos de pan y ganados y queso y lana y corderos las dos partes y la otra tercia parte le pertenece al Arcediano de Calatrava y el diezmo todo del vino le pertenece al Clavero de Calatrava», $n .^{\circ} 47$. El resto del diezmo - herrenales, huertas, pollos, garbazales - pertenecen a la Encomienda y comendador del Pozuelo, cfr. n. ${ }^{\circ} 47$.

487. «... hay otros diezmos de iglesias, ermitas e Comendador desta villa», $n .{ }^{\circ} 26$.

488. Es un anejo de Daimiel; cfr. Relaciones de Daimiel, $n .^{\circ} 26$.

489. Hemos aplicado la reducción del diezmo; el manuscrito nos habla de 29.000 y 16.000 fanegas, respectivamente. Cfr. Relaciones de Daimiel, $n{ }^{\circ} 26$.

490. El manuscrito habla de 14 a 17 cahízes. El cahiz es una medida de capacidad para áridos, variante según las regiones. En Castilla equivalia a 12 fanegas. En esta ocasión, nos extraña que Salomón haya omitido la referencia a este pueblo.

491. Las Relaciones hablan de «... dos mil hanegas a dicho Alonso de Mesa» que le corresponden por los 2/3 más 1.000 que es el tercio que corresponde al Arzobispo. También habla de un diezmo - «... de siete fanegas una»- que se paga a la Encomienda de Valdefuentes y Decillano, pero «desto no tercia el Arzobispo», cfr. n. ${ }^{\circ} 26$. 


\begin{tabular}{|c|c|c|}
\hline Pueblo & Valor del diezmo & Quién lo cobra \\
\hline \multicolumn{3}{|l|}{ Puebla de Don } \\
\hline Rodrigo & $\begin{array}{l}\text { - Trigo, cebada, } \\
\text { centeno y algún } \\
\text { ganado } \ldots \ldots \ldots 100.000 \mathrm{mrs}\end{array}$ & $-?$ \\
\hline Puertollano & - Pan $\ldots \ldots \ldots \ldots .3 .000$ fan. ${ }^{492}$ & $\begin{array}{l}\text { - 2/3 Mesa.; } 1 / 3 \text { el } \\
\text { Arzobispo }\end{array}$ \\
\hline Retuerta del Bull. & - ? ........250 a 300 fan. ${ }^{493}$ & $-?$ \\
\hline Saceruela & $\begin{array}{l}\text { - Trigo } \ldots \ldots \ldots 600 \text { a } 700 \mathrm{fan} . \\
\text { - Menudos } \ldots \ldots \ldots 85.000 \mathrm{mrs} .\end{array}$ & $\begin{array}{l}\text { - El Comendador y la } \\
\text { Mesa Maestral } 494\end{array}$ \\
\hline Sta. Cruz de $M$. & $\begin{array}{l}\text { - Pan } \ldots \ldots \ldots \ldots .4 .000 \text { fan. } \\
\text { - Ganados } \ldots \ldots \ldots .600 \text { duc. }\end{array}$ & $\begin{array}{l}\text { - } 2 / 3 \text { el Señor de la } \\
\text { Villa; } 1 / 3 \text { el Arzobispo }\end{array}$ \\
\hline Socuéllamos & $\begin{array}{l}\text { - Pan } \ldots \ldots \ldots \ldots 20.000 \text { fan. } \\
\text { - Resto } \ldots \ldots \ldots \ldots 3.000 \text { duc. }{ }^{495}\end{array}$ & - El Comendador \\
\hline \multirow[t]{2}{*}{ Solana, La } & $-\operatorname{Pan} \ldots \ldots \ldots \ldots \ldots+0.000$ fan & $\begin{array}{l}\text { - 2/3 la Encomienda; } \\
\text { 1/3 el Arzobispo }\end{array}$ \\
\hline & $\begin{array}{l}\text { - Vino } \ldots \ldots \ldots \ldots \text {. } 5.000 \mathrm{arr} . \\
\text { - Ganado } \ldots \ldots \ldots 1.500 \mathrm{cab}^{496}\end{array}$ & ( \\
\hline Terrinches & $-?^{497}$ & $\begin{array}{l}\text { 2/3 Comendador Ma- } \\
\text { yor de Castilla; } 1 / 3 \\
\text { el Arzobispo }{ }^{498}\end{array}$ \\
\hline Tirteafuera & $\begin{array}{l}\text { - Trigo } \ldots \ldots \ldots \ldots \ldots 400 \mathrm{fan} . \\
\text { - Cebada } \ldots \ldots \ldots \ldots .200 \mathrm{fan}\end{array}$ & $\begin{array}{l}\text { - 2/3 el Rey y la Mesa M., } \\
\text { 1/3 el Arzobispo }\end{array}$ \\
\hline Tomelloso & $-?$ & $\begin{array}{l}\text { - El Comendador de } \\
\text { Socuéllamos }\end{array}$ \\
\hline
\end{tabular}

492. Aquí el manuscrito nos da un dato bastante valioso, como es el rendimiento del campo: «... se siembran cada un año con otro cuatro mil fanegas de pan trigo y cebada poco mas o menos de que se cogen un año con otro treinta mil fanegas de pan», n. ${ }^{\circ} 26$.

493. El manuscrito habla de 20 a 25 cahízes, cfr. $n .^{\circ} 26$.

494. Otra modalidad de los diezmos la tenemos aquí: «... de todo lleva el Comendador los diezmos, ecepto que el cuarto año viene a la Mesa Maestral", $n .^{\circ} 26$.

495. «... entrando en ello los diezmos de las villas de las Mesas de la Mota, del Toboso de Pero Muñoz, y Campo de Criptana que labran en el termino desta villa (...) la primicia del queso, que lleva el cura», n. ${ }^{\circ} 26$.

496. Se suele arrendar el pan y el vino en $\mathbf{4 0 0 . 0 0 0 ~ m a r a v e d i ́ s ~ y ~ e n ~ o t r o ~ t a n t o ~ e l ~ g a n a d o ~ y ~ l a ~}$ lana, cfr., $n .^{\circ} 26$.

497. Se excusan y escudan en que «se coge poco» y no dan cifras, aunque también dan los resultados de las cosechas, como hemos visto más arriba, cfr. nota 469 .

498. «... y el convento de Ucles (se lleva) la decima», $n .^{\circ} 26$. 
Pueblo

Valor del diezmo

Quién lo cobra

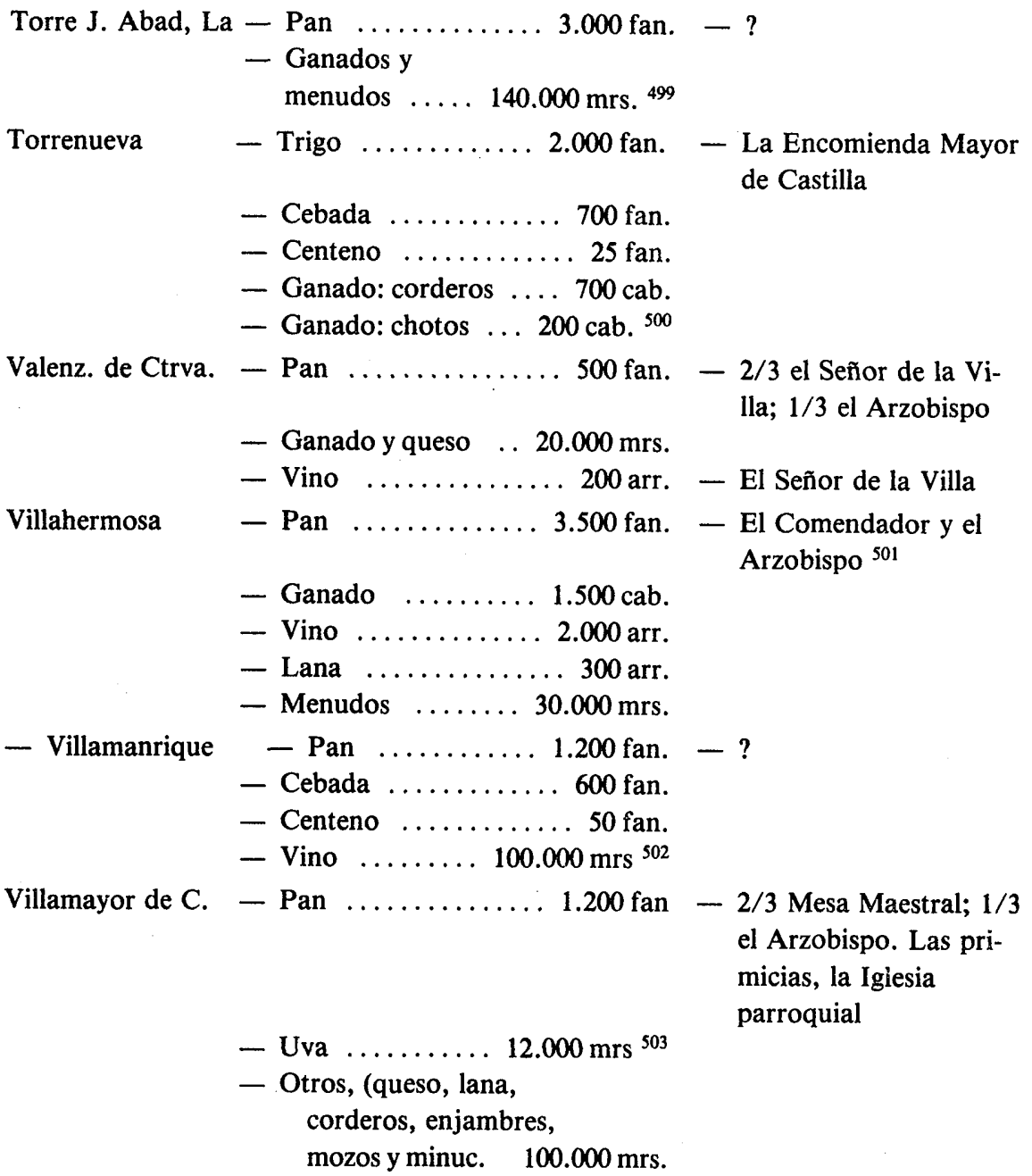

499. En esos menudos están incluidos los $1.000 \mathrm{mrs}$, que es el deizmo de huertas, árboles, hortalizas y cáñamos, cfr., $n .^{\circ} 21$.

500. Hemos aplicado la reducción del diezmo porque el manuscrito habla de cifras totales: $20.000,17.000$ y 250 fanegas, respectivamente y 7.000 y 2.000 cabezas de corderos y chotos, respectivamente, cfr., $n .^{\circ} 26$.

501. «... todos los diezmos del Comendador que se le diezmas valdran hasta tres mil ducados y demas desto diezmas los vecinos desta villa a el Arzobispo de Toledo hasta mil ducados», n. ${ }^{\circ} 26$.

502. Esos 100.000 maravedís es el precio del diezmo de 500 arrobas de vino, cfr., $n .^{\circ} \mathbf{2 6}$.

503. Comprobamos una vez más que Salomón habla erróneamente de 120.000 mrs. de vino 
Pueblo

Villarta de S. J.

Valor del diezmo

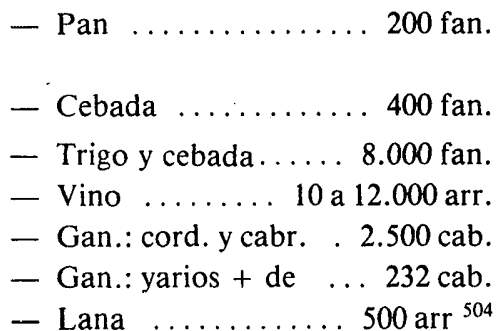

Villarrubia de los

Ojos

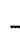

- Trigo

- Cebada 644 fan y 11 cel

1.495 fan.

- Candeal .... 176 fan. y 11 cel.

- Centeno .......... 128 fan.

- Vino ......... $149.000 \mathrm{mrs}$.

- Lana ............ 80 arr.

- Menud. . 346.374 mr. + 12 duc.

Viso del Marqués 450 fan

\section{Quién lo cobra}

- 2/3 el Prior de San

Juan; $1 / 3$ el Arzobispo.

- Trigo $\ldots \ldots \ldots \ldots \ldots .450$ fan.
- Cebada $\ldots \ldots \ldots \ldots .187,5$ fan.
- Centeno $\ldots \ldots \ldots \ldots \ldots \ldots 6$ fan.
- Vino $\ldots \ldots \ldots \ldots \ldots 67.500$ mrs.
- Ganado $\ldots \ldots \ldots \ldots .450$ duc ${ }^{505}$

-cfr. o.c., págs. 378-379- suma demasiado elevada para un pueblo tan pequeño en territorio y habitantes y que, además, no se considera recolector de uva porque cuando habla del vino, dice: «... tiene falta de vino, proveese de la mancha», $n .^{\circ} 26$. Referente a las primicias que cobra la Iglesia consiste en media fanega de cereal por cada doce que recoja el labrador, cfr. $n .^{\circ} 26$.

504. «... págase desto (ganado) el diezmo a dinero», $n .^{\circ} 26$, pero no indica la cantidad.

505. Nos admiramos nuevamente que el profesor Salomón —cfr. o.c., págs. 378-379- escoja.los diezmos cobrados el año 1574 y no los de 1575 , que indican los dos, o, teniendo en cuenta la gran diferencia de las cifras, no cite en nota las del otro año. Nosotros hemos optado por indicar las de 1575 - año de la redacción de las Relaciones- e indicar las del año anterior y, además, señalar como dato precioso que una anomalía climática, meteorológica, o cualquier tipo de inestabilidad, puede desequilibrar totalmente una ya quebrada y deficitaria agricultura, con el desencadenamiento de efectos negativos que ya sabemos se originan. En el manuscrito sólo indican las cifras correspondientes a los $2 / 3$ del Señor de la villa, pero para una correcta valoración y unificación, como en otros casos hemos aumentado 1/3 del Arzobispo.

Diezmos correspondientes a 1575 :

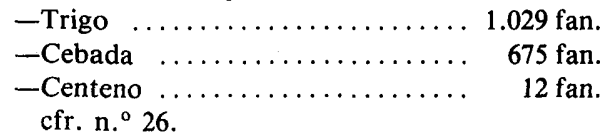


Valor de los diezmos (resumen):

-Sobre 61 pueblos estudiados:

- Tratando de conseguir una cierta unificación, manteniendo la fidelidad al texto, hemos reducido las cifras de dinero, cuando venían indicadas en ducados - pocas veces - a maravedises, utilizando el cambio indicado en el manuscrito de 1 ducado igual a $\mathbf{3 7 5}$ maravedises.

- El «pan» que se indica a continuación es un concepto de cereal compuesto por trigo y cebada, casi siempre, y en partes iguales. «Pan por mitad», como indica numerosas veces el manuscrito.

- Las cifras no pueden ser exactas, porque tampoco lo son en su fuente; en muchas ocasiones el manuscrito nos habla de : tal o tal cantidad, aproximadamente, más o menos, etc.

- En el concepto de "otros» incluimos ciertos aspectos ya reseñados y otros nuevos pero cuyas cifras se nos dan de forma global.

- Nuevamente tenemos que hacer constar la no coincidencia de las cifras totales y parciales de nuestro estudio con las de N. Salomón —cfr. o.c., págs. 376 y 379 - por el hecho de haber estudiado más pueblos que él y haber obtenido otros resultados, como indicamos en muchos casos.

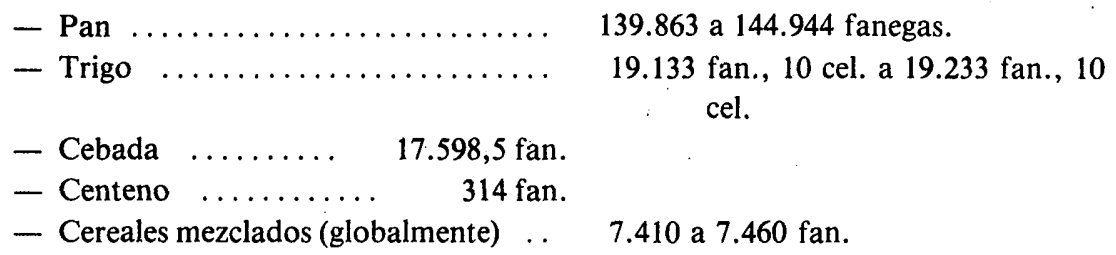

Vino:
- en dinero
1.317 .500 a $1.327 .500 \mathrm{mrs}$.
- en especie.....$\ldots \ldots \ldots \ldots$.
45.940 a 47.940 arrobas.
- en dinero
1.548 .250 a $1.556 .250 \mathrm{mrs}$.
- en especie
7.352 cabezas.
Ganado, lana y queso (globalmente):
$\begin{array}{llll}\text { - en dinero } \ldots \ldots \ldots \ldots \ldots \ldots \ldots \ldots & 1.645 .000 \text { a } 1.682 .500 \mathrm{mrs} . \\ \text { - en especie } \ldots \ldots \ldots \ldots \ldots \ldots \ldots & 1.180 \text { arrobas. } \\ \text { - Menudos o minucias } & \ldots \ldots \ldots \ldots \ldots & 4.770 .874 \mathrm{mrs} . \\ \text { - Otros (globalmente) } & \ldots \ldots \ldots \ldots \ldots & 3.546 .500 \text { a } 3.552 .500 \mathrm{mrs} .\end{array}$

Ganado:

Quién cobra los diezmos (resumen):

- Sobre 61 pueblos estudiados:

- La complejidad del reparto y la falta de información en muchos casos hace casi imposible la evaluación exacta; no obstante indicamos un reparto aproximativo y orientador. 
Beneficiarios de los diezmos

- El Arzobispo de Toledo

- Encomienda o Comend. respectivo .

- La Mesa Maestral ...............

- El Rey

- Señor de la Villa respec.

- Otros (Prior, Maestre, Arcedia.) ...

- No responden

Valor de los diezmos reducidos a dinero:

- Pan (media trig. y ceb: 7,41 rs./fan.)

- Trigo (media: 8,7 rs./fan)

- Cebada (media: 6,12 rs./fan.) ....

- Centeno (media: $4,75 \mathrm{rs} / \mathrm{fan}$.) ....

- Cereales mezclados (media de T., C., C.: 6, 52 rs./fan.)

- Ganado (media: 293,73 mrs./cab.) .

- Ganado: indicado ya en dinero ....
N. ${ }^{\circ}$ de pueblos en los que cobra

21
15
12
10
4
5
23

$\%$ aproximativo de de lo que cobra

$21 \quad 1 / 3$

$151 / 3,2 / 3$ y/o todo

$12 \quad 2 / 3$ y/o todo

$10 \quad 2 / 3$ y/o todo

$4 \quad 2 / 3$

5. $1 / 3,2 / 3 \mathrm{y} / \mathrm{o}$ todo

23 ?

$\begin{array}{rc}1.036 .384,8 \mathrm{a} & 35.237 .083 \mathrm{a} \\ 1.074 .035 & 36.517 .190 \\ 166.457,97 \mathrm{a} & 5.659 .570 \mathrm{a} \\ 167.327,97 & 5.689 .150,9 \\ 107.790,8 & 3.664 .887,5 \\ 1.491,5 & 50.711 \\ & \\ 48.350,25 \mathrm{a} & 1.643 .908,5 \\ 48.676,5 & 1.655 .001 \\ - & 2.159 .650 \\ - & 1.548 .250 \mathrm{a} \\ & 1.556 .250\end{array}$

- Del resto de conceptos podemos señalar el valor aproximativo por carecer de precios de referencia en el manuscrito o venir expresados globalmente y tratarse de conceptos, cantidades y precios muy diversos.

Pueblos

Albadalejo

n. ${ }^{\circ} 26$

Almadén

n. ${ }^{\circ} 26$

Santa Cruz de Mudela

n. ${ }^{\circ} 26$

Villarrubia de los Ojos n. ${ }^{\circ} 26$

\section{Precio de los productos}

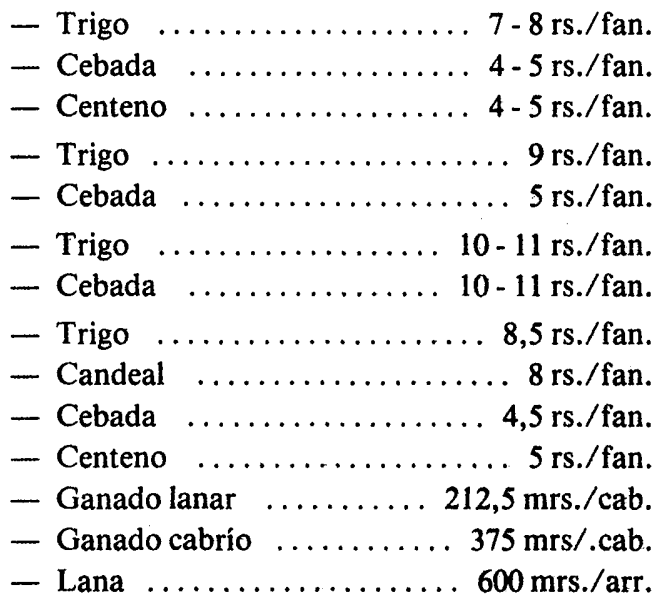

Medias aproximativas: Trigo: 8,7 rs.; Cebada: 6,125 rs.; Centeno: 4,75 rs./fan. respectivamente. 
Pueblo

Puertollano

n. ${ }^{\circ} 26$

Terrinches

n. ${ }^{\circ} 26$
Rendimiento del campo

- Se recogen 7,6 fan./por 1 de sembradura

- Se recogen 4 ó 5 fan./ por 1 de sembradura

Media aproximativa: 6 fan./ por 1 de sembradura.

Pueblo

Villarrubia de los Ojos

n. ${ }^{\circ} 26$

\section{Equivalencia del dinero}

-1 ducado $=375$ maravedises.

-1 real $=34$ maravedises.

Nota: El número debajo de cada pueblo remite al manuscrito - Relaciones del pueblo correspondiente - de donde hemos tomado las respectivas equivalencias.

\section{Conclusión}

Nuestra tarea ha sido la de rescatar, ordenar y clasificar todo este valioso cúmulo de información, casi virgen, para que sirva a posteriores trabajos y estudiosos del fecundo siglo XVI español.

Nos hemos acercado algo más a la realidad concreta dẹl pueblo un poco olvidado en monografías o en estudios generales y en el campo específico de cómo manifiesta sus creencias religiosas colectiva y públicamente.

Llama la atención poderosamente el hecho de que en los capítulos estudiados nos hayamos encontrado el dato de que en la mayoría de los pueblos las instituciones - cofradías, ermitas, votos, hospitales, monasterios, etc.son de reciente creación, lo que se puede interpretar como una puesta a punto para empezar a funcionar, hecho sorprendente si lo encuadramos con la fecha relativamente tardía de la redacción de estos documentos.

También hemos comprobado en el apartado de la jurisdicción que muchos de los pueblos están siendo desmembrados de las antiguas Órdenes Militares, en ese momento ya incorporadas a la Corona con sus posesiones, por medio de compraventa por señores particulares, miembros de la nobleza. Posiblemente haya que buscar la razón de este trasvase Corona-nobleza en la necesidad imperiosa de salir de los apuros económicos de la administración de los primeros Austrias, en los vencimientos inexorables de los préstamos de banqueros extranjeros y la necesidad de conseguir dinero y en la continua sangría que las campañas europeas de Carlos I y Felipe II exigieron duros sacrificios a los pueblos de Castilla. Otro dato significativo a este respecto, es el que en los pueblos donde el Rey ejerce dominio directo son los más pobres en rendimiento y menos importantes en población. 
Las órdenes Militares habían dejado su dominio directo sobre los pueblos. Adriano VI, el 4-mayo-1523, de acuerdo con el Sacro Colegio Cardenalicio agregó e incorporó perpetuamente a la Corona de Castilla y Aragón los Maestrazgos de las Órdenes Militares, aun cuando la Corona recayese en hembra, si bien había que nombrar a personas religiosas para la jurisdicción espiritual, que la ejercerían «ad nutum». Posteriormente Clemente VII, el 15marzo-1529, confirmaría la incorporación de Adriano VI. Sin embargo, las Órdenes Militares conservan una fuerza e influencia real y efectiva sobre estos pueblos que se manifiesta en la autoridad de los Visitadores, en la recaudación de un $\%$ de los diezmos y en otras posesiones - puentes, dehesas, etc.-

El significado de la figura del arzobispo de Toledo es casi de protagonista y el valor efectivo, moral y económico, muy considerable. Teniendo en cuenta que su autoridad eclesiástica es total y respaldada por unos ingresos sustanciosos, que aunque en cada pueblo no sean muy cuantiosos, sin embargo comprende a casi todos los pueblos, amén del poder político que conlleva su puesto. Cierto que el valor de la mitra va unido a la autoridad, poder y funciones del cargo -omnímodo sobre las conciencias de los fieles- sin atender demasiado a la persona que en cada momento ostente la dignidad. No olvidemos que en ninguno de los pueblos hemos encontrado la más mínima alusión crítica que signifique pérdida de prestigio de la dignidad arzobispal y en estos momentos es Fray Bartolomé de Carranza el que ostenta la mitra toledana, cuando sufriendo tribulación en la fortaleza de Sant'Angelo de Roma ya próxima la sentencia tras el inicuo proceso, se acerca su fin.

La piedad del pueblo queda sobradamente manifiesta en infinidad de fundaciones, obras pías, hospitales, capellanías, etc. donde por remediar las muchas angustias de pobres y necesitados, les llevan a este tipo de obras de misericordia; el problema ya apuntado es poder conocer si en la raíz de lo hechos no hay otros motivos que no sean totalmente religiosos, pero escapa a nuestras posibilidades evaluar la conciencia y las intenciones humanas. Sí hay sugerencias que nos hacen pensar o sospechar una mala, incorrecta, interesada o deformada formación y conciencia religiosa.

El temor al castigo divino o celestial -tempestades, plagas, fenómenos meteorológicos, etc. - o el deseo de propiciación, también divina, hacen que muchas conductas y hechos colectivos se rijan por el deseo de obtener los mejores rendimientos de cosechas, ganados y salud física.

El capítulo de reliquias y milagros es donde más se puede notar la inocencia, falta de formación, sólida creencia, o misteriosos residuos atávicos de falsas creencias, pero perdurables en la gente sencilla, posiblemente sin plena conciencia de por qué creían así y en eso.

Sin profundizar demasiado, porque no era nuestro objetivo sino sólo tan- 
gencialmente para mejor comprender el hecho y vivencia religiosas, observamos que la propiedad señorial se mezcla con la comunitaria -en recesión-y la particular, todavía no muy significante; lo que nos indica una pervivencia de cierto sistema de tipo feudal, donde la mayor parte de la propiedad y centros económicos está en manos de la nobleza, Órdenes Militares y clero y con un sistema de producción no evolucionado.

Se respira un aire de creación de nuevas formas y modos o maneras sobre patrones antiguos; un intento de modificar la apariencia externa manteniendo inalterable el contenido. No olvidemos que la sociedad española y las instituciones se encauzaron y apostaron en estos momentos por la continuidad, rechazando y abjurando, como frívolo y pecaminoso, el cambio, que era la modernidad y el futuro. Las relaciones de Felipe II son una verificación de este hecho. 